\title{
Overview on the Fungal Metabolites Involved in Mycopathy
}

\author{
Abdulkawi Ali Al-Fakih \\ Department of Medical Microbiology, Faculty of Science, Ibb University, Ibb, Yemen \\ Email: Fakeeh16@yahoo.com
}

Received 27 September 2013; revised 28 October 2013; accepted 4 November 2013

Copyright (C) 2014 by author and Scientific Research Publishing Inc.

This work is licensed under the Creative Commons Attribution International License (CC BY). http://creativecommons.org/licenses/by/4.0/

(c) (†) Open Access

\section{Abstract}

This review presents several types of metabolites produced by the most common fungal pathogens and their roles in fungal pathogenesis. Toxic metabolites from toxigenic fungi include compounds such as aflatoxins, trichothecenes, ochratoxins, fumonisins, zearalenone and ergot alkaloids, which display hepatotoxicity, nephrotoxicity, neurotoxicity and genotoxicity. The ability of fungi to produce and elaborate hydrolytic enzymes is associated with virulence of several pathogenic fungi. The biogenesis of siderophores is investigated as it is a mechanism of iron acquisition. In particular, these metabolites act as iron chelators and storage compounds to support pathogenic fungi to survive in mammalian hosts whose iron homeostasis is strictly regulated and prevent the formation of free radicals which are formed by free iron. Melanins clearly promote infectivity in a number of species of fungal pathogens. They interfere with oxidative metabolism of phagocytosis making the fungus relatively resistant to phagocyte attack. Several metabolies such as pullulan, mannitol, $\beta$ - $(1,3)$-glucan, hem-binding proteins, estrogen-binding proteins, farnesol, agglutinin-like sequence proteins, glucuronoxylomannan and others also have advantages in fungal pathogenicity. The identification of fungal metabolites involved in pathogenesis, and recognition of mechanisms of pathogenesis may lead to development of new efficient anti-fungal therapies.

\section{Keywords}

Fungal Metabolites; Pathogenesis; Mycotoxicoses; Mycoses

\section{Introduction}

Fungi are ubiquitous, eukaryotic microorganisms which found in many different environments wherever organic material is available. They are found in a wide range of environments due to their capacity to utilize a variety of 
substrates and to their relative tolerance to low $\mathrm{pH}$, low water activity and low temperature [1]. A number of fungi are symbiotic and may live in commensalism, mutualism or parasitism with other organisms. However, only some of the fungal species are pathogenic to man. Human fungal pathogens belong to four main groups, namely zygomcetes, ascomycetes, deuteromycetes and basidiomycetes [2]. Fungi can synthesize a vast diversity of chemical compounds either of primary or secondary metabolism origin. Contrary to primary metabolites, secondary metabolites are not necessary for normal growth or development, but often have potent physiological activities [3]. These metabolites are of a great importance to humankind due to their involvement in pathogenicity [4]. Most fungal secondary metabolites are produced after the fungus has completed its initial growth phase [5]. According to chemical structure, fungal secondary metabolites may be polyketides (e.g. aflatoxin and fumonisins), non-ribosomal peptides (e.g. sirodesmin, peramine and siderophores such as ferricrocin), terpenes (e.g. $\mathrm{T}-2$ toxin and deoxynivalenol), or indole terpenes (e.g. paxilline and lolitrems) [6]. Toxic metabolites from fungi include compounds such as aflatoxins, trichothecenes, ochratoxins, fumonisins, zearalenone, ergot alkaloids and others [7]. Some fungi can produce iron chelators (siderophores) such as hydroxamates to solubilize Fe(III) to make it available for uptake [8]. Other fungal metabolites such as melanins, enzymes, carotenoids and others have also been described. Exposures to toxic fungal metabolites (mycotoxins) produce diseases collectively called mycotoxicoses, while growth of fungi on human and animal results in diseases collectively called mycoses [7]. This review deals with various metabolites synthesized by fungi having significance roles in mycopathy.

\section{Virulence, Pathogenicity and Mycopathy}

Mycologists estimate that there are 100,000 species of fungi in nature. However, only about 300 species have been linked to diseases in humans and animals. In general, the term pathogenicity refers to the ability of an organism to cause disease. This property is the result of a direct interaction between the pathogen and the host. In many ways, pathogenicity and virulence are very broadly defined terms. With the exception of a few dermatophytes, pathogenicity among the fungi is not necessary for the maintenance or dissemination of the species [9]. Mycopathy is a collective term used for diseases caused by fungi either living or dead or their metabolic products (toxins, allergins or enzymes). This complex term comprises disease manifestations such as mycotoxicosis and mycoses [10]. Mycotoxicoses occur when mycotoxins enter the body, usually by consumption of contaminated feed. Mycotoxicoses are not contagious and mycotoxins do not stimulate the immune system. On the other hand, mycoses occur when fungi infect tissues of the body. Mycosis can be contagious and may lead to stimulation of the immune system. Fungal pathogens can enter the body through respiratory, mucous and cutaneous routes. Immunity to fungal infections consists of nonspecific barriers, inflammation and cell-mediated immune responses [11]. Several determinants including genes or gene products known as virulence factors are involved in this relationship, producing superficial to invasive infections in humans [2] [9]. Virulence factors are molecules that enable pathogen to achieve colonization of host tissues (this includes adhesion to cells), evasion and/or inhibition of the host's immune response. Fungal pathogens possess a wide array of virulence factors. Some of them are produced and secreted to the tissue environment of the host, and others may remain inside the fungus or as structural molecule but have roles in fungal pathogenicity. Furthermore, the ability of an organism to adapt quickly to new environmental challenges is itself likely to be an effective virulence mechanism, in that it enables the pathogen to take advantage of new opportunities [12] [13].

\section{Fungal Metabolites Involved in Mycotoxicoses}

Mycotoxicosis is the term used for intoxication associated with exposures to mycotoxins [7] [14]. The term mycotoxin simply means a toxin produced by a fungus. Mycotoxins are low-molecular weight natural products produced as secondary metabolites by toxigenic species of microscopic filamentous fungi, which can cause toxic effects in humans and animals [7] [15] [16]. These toxins have no biochemical significance in fungal growth and development [17]. Toxigenic molds are known to produce one or more of these toxic secondary metabolites. Several types of fungal species of Fusarium, Aspergillus, Penicillium, Cladosporium, Claviceps, Alternaria and Helminthosporium have been reported to produce mycotoxins [18]. One mold species may produce many different mycotoxins, and the same mycotoxin may be produced by several species. Mycotoxins can be clinically classified into hepatotoxins, nephrotoxins, neurotoxins, immunotoxins and others [7]. They are present in many 
food items of vegetable and animal origin as well as in the air [19]. In low concentrations, mycotoxins are toxic and introduced to humans via ingestion, contact and inhalation [20]. On the other hand, other low-molecular weight fungal metabolites such as ethanol that are toxic only in high concentrations are not considered mycotoxins [21]. Contamination of food with mycotoxins is caused either by direct contamination of grains, fruits and their products or by "carry-over" of mycotoxins and their metabolites in animal tissues, milk and eggs after intake of contaminated feedstuff [22]. About 300 - 400 mycotoxins are known, but most of them do not have an impact on the health of human and animal beings, simply because they do not occur in substantial amounts in foods and feeds [23]. The mycotoxins that pose the greatest potential risk to human and animal health as food and feed contaminants are aflatoxins, trichothecenes, fumonisins, zearalenone, ochratoxin A and ergot alkaloids [7] [24]. These toxins and their major toxigenic species of fungi are presented in Table 1 . However, other mycotoxins should be included because of their frequency of occurrence in commodities or their products or their co-occurrence with other important mycotoxins. This expanded list includes cyclopiazonic acid, sterigmatocystin, gliotoxin, citrinin, penitrems, patulin and miscellaneous mycotoxins such as fusarin C, fusaric acid, penicillic acid, mycophenolic acid, roquefortine, PR toxin and others [24]. Mycotoxicosis can be categorized as acute or chronic. Generally, acute toxicity has a rapid onset and an obvious toxic response, while chronic toxicity is characterized by low-dose exposure over a long time period, resulting in cancers and other generally irreversible effects [25].

\subsection{Aflatoxins}

Aflatoxins are one of the most potent mycotoxins produced by fungi Aspergillus flavus and A. parasiticus in/on foods and feeds [26], and another producers have been reported [27] [32]. Aflatoxins were first isolated and characterized after outbreaks of disease and death in turkeys (turkey $\times$ disease) and cancer in rainbow trout fed on rations formulated from peanut and cottonseed meals [33]. Based on chemical structure, aflatoxins are difuranocoumarin derivatives produced by a polyketide pathway by many fungal-strain producers [7]. The diseases caused by aflatoxins consumption are called aflatoxicoses, which reported in humans in many parts of the world. Aflatoxins can cause acute and chronic health effects including immune suppression, growth retardation, cancer and, in severe acute exposure, death [34]-[37]. Aflatoxins can cause disease throughout the body, but are most commonly known for causing acute or chronic liver disease and liver cancer. On the basis of acute toxicity, aflatoxins are considered among the most potent hepatotoxins within the different variants and are by far the most studied [38]. There are six major chemical forms of the aflatoxins, including aflatoxins B1, B2, G1, G2, M1 and M2 [39]. Aflatoxins B1 and B2 fluoresce blue under shortwave UV, while aflatoxins G1 and G2 fluoresce green. Aflatoxins M1 and M2 are the forms that B forms are converted to through metabolic processes in animals and are excreted in milk [14]. Aflatoxin B1 (Figure 1) is the most potent natural carcinogen known [40], and is usually the major aflatoxin produced by toxigenic strains [7]. Hepatocarcinogenicity of aflatoxins are mainly attributed to adduct formation with DNA, RNA and protein. In addition, aflatoxins also cause lipid peroxidation as well as oxidative damage to DNA [41] [42].

\subsection{Trichothecenes}

Trichothecenes are a family of mycotoxins which include over 180 structurally-related compounds produced by several fungal genera, especially Fusarium, Stachybotrys, Trichothecium, Trichoderma, Memnoniella, Phomop-

Table 1. The major mycotoxins and their producers.

\begin{tabular}{cc}
\hline Mycotoxin & Fungal species \\
\hline Aflatoxins & Aspergillus flavus, A. parasiticus, A. nomius, A. tamarii, A. pseudotamarii, A. bombycis, A. ochraceoroseus \\
Trichothecenes & Fusarium, Stachybotrys, Trichothecium, Trichoderma, Memnoniella, Phomopsis, Myrothecium \\
Ochratoxins & Aspergillus ochraceus, A. carbonarius, Penicillium verrucosum. \\
Fumonisins & F. verticillioides, F. proliferatum \\
Zearalenone & F. graminearum, F. culmorum F. equiseti F. crookwellense \\
Ergot alkaloids & Claviceps purpurea \\
\hline
\end{tabular}




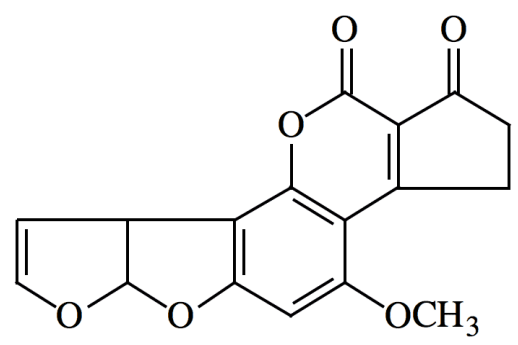

Figure 1. The chemical structure of aflatoxin B1.

sis and Myrothecium [43]-[46]. Chemically, they are sesquiterpene compounds that consist of the trichothecene core with epoxy rings at C-12 and -13 positions. All trichothecenes contain a common 12,13-epoxytrichothene skeleton and an olefinic bond with various side chain substitutions [7]. According to the presence of a macrocylic ester or an ester-ether bridge between C-4 and C-15, trichothecenes are classified into macrocylic and nonmacrocyclic trichothecenes [47]. Fusarium is the major genus implicated in producing the non-macrocylic trichothecenes [7]. From a public health perspective, trichothecenes belonging to three structural groups appear to be most important: type A trichothecenes which have isovaleryl, hydrogen, or hydroxyl moieties at the C-8 position (e.g., T-2 toxin), Type B trichothecenes which have a carbonyl group at the C-8 position (e.g., deoxynivalenol) and the Type D (macrocyclic trichothecenes), which have a cyclic diester or triester ring linking C-4 to C-15 (e.g., satratoxin G) [48]. Trichothecenes are commonly found world-wide on cereals such as wheat, rye, barley, oats and corn [49]. T-2 toxin (Figure 2) is the most toxic type A trichothecene [50]. Trichothecenes have been associated with human health hazards and the reported health implications range from nausea, vomiting, skin irritation and internal bleeding to respiratory disorders of various kinds [51]. T-2 toxin can cause severe skin irritation (erythema, edema and necrosis) and vesication [52]. Deoxynivalenol (Figure 3) can cause immune stimulation and suppression in leukocytes by upregulating gene expression and apoptosis, respectively [53]. Deoxynivalenol inhibits intestinal cell proliferation and is absorbed through the intestinal epithelium by simple diffusion [54]. In addition, trichothecenes can activate inflammatory response in human macrophages [55]. Trichothecenes have also been linked to indoor air illness [56]-[58]. Mechanistically, trichothecenes are powerful inhibitors of protein synthesis, inhibition of mitochondrial function and they can interact with the cell membrane [24] [46]. They bind to the peptidyl transferase center of the 60S ribosomal subunit and prevent polypeptide chain initiation or elongation [59] [60]. In addition, it is known that trichothecenes rapidly activate mitogen-activated protein kinases and induce apoptosis in a process known as the "ribotoxic stress response" [61]-[64].

\subsection{Ochratoxins}

Ochratoxins are a family of chemically related mycotoxins produced by several species of Aspergillus and Penicillium [65]. Chemically, they are pentaketides made up of dihydroisocoumarin linked to L- $\beta$-phenylalanine [66]. Ochratoxins consists of three members, A, B and C that differ slightly from each other in chemical structures. These differences, however, have marked effects on their respective toxic potentials. The most important and most toxic ochratoxin found naturally in food is ochratoxin A (Figure 4) [67] [68]. It was first discovered in 1965 in an Aspergillus ochraceus isolate [69]. It is also produced by Penicillum verrucosum during the storage of cereals, cereal products and other plant-derived products [70]. Ochratoxins contamination of foods and feeds poses a serious health hazard to animals and humans [66]. Ochratoxin A has been shown to be nephrotoxic, hepatotoxic, teratogenic, carcinogenic, genotoxic and immunosuppressive [66] [71] [72]. The primary effects of ochratoxin A are associated with the enzymes involved in phenylalanine metabolism, mostly by inhibiting the enzyme involved in the synthesis of the phenylalanine tRNA complex [73]. In addition, it inhibits mitochondrial ATP production [74] and stimulates lipid peroxidation [75]. Ochratoxin A is believed to be responsible for a human disease called endemic Balkan nephropathy [76] [77], which is a form of interstitial nephritis that occurs among several small, discrete communities along the Danube River and its major tributaries, in the modern countries of Croatia, Bosnia and Herzegovina, Serbia, Romania and Bulgaria [7] [78]. 


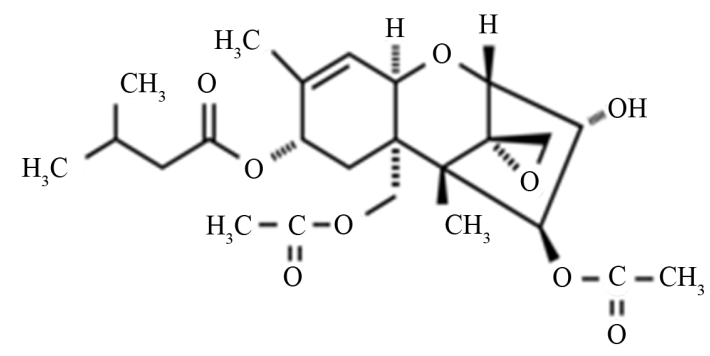

Figure 2. The chemical structure of T-2 toxin.<smiles>C=C1[C@H]2C[C@H](O)[C@@H]3O[C@H]2C=C(C)C(=O)[C@H]3[C@@]1(C)O</smiles>

Figure 3. The chemical structure of deoxynivalenol.<smiles>C[C@@H]1Cc2c(Cl)cc(C(=O)N[C@@H](Cc3ccccc3)C(=O)O)c(O)c2C(=O)O1</smiles>

Figure 4. The chemical structure of ochratoxin A.

\subsection{Fumonisins}

Fumonisins are a group of mycotoxins produced by fungi of the genus Fusarium such as F. verticillioides and $F$. proliferatum [79]. Another producers rather than Fusarium have been reported and there are about 53 different fumonisins [80], but fumonisins B1 (Figure 5), B2 and B3 are all carcinogenic and regarded as the most important [81] [82]. Generally, the human health problems related to fumonisins are almost exclusively associated with the consumption of contaminated maize or products made from maize [83]. The main effects of fumonisins include inhibition of ceramide synthase, causing accumulation of bioactive intermediates of sphingolipid metabolism (sphinganine and other sphingoid bases and derivatives) in many types of cells and tissues, including hepatocytes, neurons and renal cells as well as depletion of complex sphingolipids, which interferes with the function of some membrane proteins, including the folate-binding protein (human folate receptor alpha) [84] [85]. There has been findings that fumonisins are suspected risk factors for esophageal [83] and liver [60] cancers, neural tube defects [84] [86] and cardiovascular problems [87] in people consuming relatively large amounts of food made with contaminated maize.

\subsection{Zearalenone}

Zearalenone (Figure 6) is a polyketide mycotoxin with potent estrogenic activity [88]. Hence, it also has been called a phytoestrogen, a mycoestrogen and a growth promotant [7]. It is produced by species of the genus Fusarium such as F. graminearum, F. culmorum [89]-[91], F. equiseti and F. crookwellense [7]. Zearalenone is found worldwide as a contaminant in cereals and grains, including maize [92] [93]. Despite its low acute toxicity and carcinogenicity [7], zearalenone exhibits estrogenic and anabolic properties [94]. In relation to the toxic effects in human beings, it has been claimed that premature puberty in Puerto Rico [95] and in children aged between 7 and 8 years [96] might be due to zearalenone and related compounds in the human diet. Some reports have shown the occurrence of zearalenone in food products based on maize [93]. Meucci et al. [97] detected the 


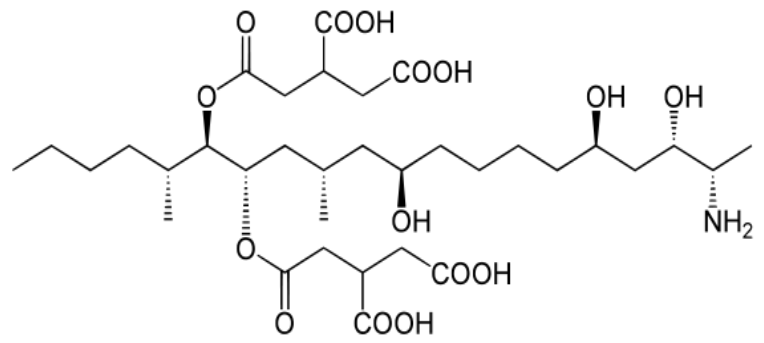

Figure 5. The chemical structure of fumonisin B1.<smiles>C[C@H]1CCCC(=O)CCC/C=C/c2cc(O)cc(O)c2C(=O)O1</smiles>

Figure 6. The chemical structure of zearalenone.

zearalenone derivatives $\alpha$-zearalenol and $\beta$-zearalenol in some milk samples as infant foods. In addition, Bandera et al. [98] detected the zearalenone in urine in $78.5 \%$ of the New Jersey girls that intake beef and popcorn. They suggested that zearalenone may exert anti-estrogenic effects similar to those reported for isoflavones. The harmful effects of zearalenone may be increased through its derivatives, $\alpha$-zearalenol, $\beta$-zearalenol, $\alpha$-zearalanol and $\beta$-zearalanol. Zearalenone and its derivatives have the remarkable ability to mimic estrogen, acting as an estrogen receptor agonist [99]-[101]. In addition, zearalenone has been found to suppress the activation of NFkB, the major transcription factor associated with the production of pro-inflammatory cytokines and enzymes [102].

\subsection{Ergot Alkaloids}

Ergot alkaloids are a complex family of indole-derived alkaloids, which are derived from the amino acid tyrptophan [103] [104]. They are produced primarily by several species of Claviceps (e.g. C. purpurea) that are plant pathogenic, and elaborate their toxins in specialized masses of fungal tissue called sclerotia [24]. These pathogenic fungi infect grain, and especially rye is very susceptible because of its open-pollinated grain [105]. In addition, there are other alkaloids-producing fungi such as Balansia spp. [106], Penicillium citrinum [107], Neotyphodium spp. [108] and Aspergillus fumigatus [104] [109]. According to their chemical similarities, ergot alkaloids can be divided into four major groups: the clavines, the lysergic acids, the lysergic acid amides and the ergopeptines [110]. All ergot alkaloids can be considered as derivatives of the tetracyclic compound 6-methylergoline [111]. Consuming grains or grain products contaminated with the sclerotia of the fungus leads to gangrenous and convulsive (neurological) forms of ergotism known as St. Anthony's fire or holy fire [7]. Ergotism is one of the oldest mycotoxicoses known, although occurrence of the disease has declined over time [24]. The gangrenous form of ergotism affects the blood supply to the extremities, while convulsive ergotism affects the central nervous system [14] [112]. Ergotamine (Figure 7) and its derivatives share structural similarities with the adrenergic, dopaminergic and serotonergic neurotransmitters and therefore have wide-ranging effects on the physiological processes that they mediate [113]. On the other hands, many of ergot alkaloids are pharmacologically active and are consequently used as drugs [103].

\subsection{Other Mycotoxins}

Fungi are potential source of several other toxic secondary metabolites such as citrinin, patulin, roquefortine C, PR toxin, cyclopiazonic acid and beauvericin. Citrinin is a yellow mycotoxin produced by several species of $P e-$ nicillium (e.g. P. verrucosum and P. camemberti) and Aspergillus (e.g. A. terreus, A. niveus and A. oryzae) [114]. Recently, citrinin has also been isolated from industrial species used to produce red pigments Monascus ruber 


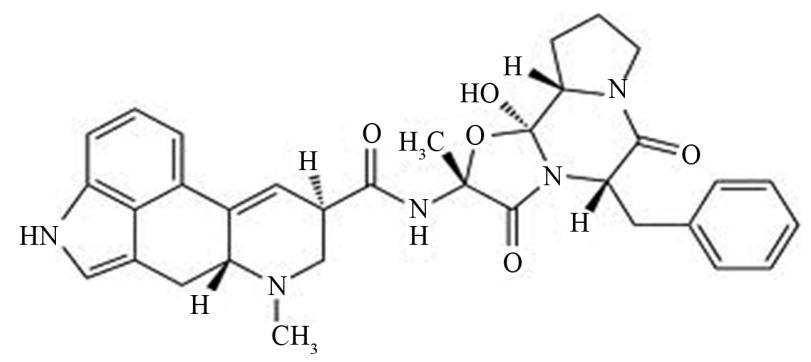

Figure 7. The chemical structure of ergotamine.

and Monascus purpureus [115]-[117]. Like ochratoxin A, citrinin is a nephrotoxin and can act synergistically with ochratoxin A to depress RNA synthesis in murine kidneys [118]. Chagas et al. [119] found that citrinin has an effect on $\mathrm{Ca}^{2+}$ transport in isolated kidney cortex and liver mitochondria, and baby hamster kidney cultured cells. It is significantly inhibited the activity of 2-oxoglutarate and pyruvate dehydrogenases in both kidney cortex and liver mitochondria. Patulin is a polyketide produced by several species belonging to Penicillium, Aspergillus, Paecilomyces and Byssochlamys. It is the most common mycotoxin found in apples and apple-derived products such as juice, cider, compotes and other food intended for young children [120]. It was first isolated as an antimicrobial agent during the 1940s from Penicillium patulum (now called Penicillium griseofulvum). Due to its toxicity to humans and animals, patulin was reclassified as a mycotoxin during the 1960s [7]. Exposure to patulin is associated with immunological, neurological and gastrointestinal outcomes [120]. Roquefortine C has received attention because of its neurotoxic properties [121]. It is produced by $P$. roqueforti and $P$. crustosum. PR toxin inhibits RNA and protein synthesis [122], the activities of the DNA polymerases $\alpha, \beta$ and $\gamma$, and mitochondrial respiration and oxidative phosphorylation in animal cells [123]. Cyclopiazonic acid is an indole tetramic acid produced by several species of Penicillium (e.g. P. aurantiogriseum) and Aspergillus (e.g. A. flavus). It is a specific inhibitor of calcium-dependent ATPase in the sarcoplasmic reticulum that results in altered cellular $\mathrm{Ca}^{2+}$ levels [124]. In addition to cyclopiazonic acid, A. flavus can produce a toxin called aflatrem contributing to the toxicity of A. flavus-infected crops. This toxin is a potent tremorgenic mycotoxin known to lead to neurological disorders [124]. Beauvericin is a cyclic hexadepsipeptide first studied for its insecticidal properties [125], and occurs naturally on corn and corn-based foods and feeds [126]. It is produced by some Fusarium species (e.g. Fusarium proliferatum, F. semitectum and F. subglutinans). Beauvericin is a specific cholesterol acyltransferase inhibitor [127] and is toxic to human cell lines of myeloid origin [128]. Various metabolites produced by A. fumigatus which may act as toxins in the host cell include fumagillin, fumigacin (helvolic acid), fumitremorgins, phthioic acid and gliotoxin. Gliotoxin in particular has been fingered as a likely virulence factor due to its cytotoxic [129], genotoxic [130] and apoptosis stimulating properties [131]. More recently, there is a novel mycotoxin named acrebol, consisting of two closely similar peptaibols, has been isolated from an indoor strain of the fungus Acremonium exuviarum, and it was found that inhibited complex III of the respiratory chain of the tested rat liver mitochondria [132].

\section{Fungal Metabolites Involved in Mycoses}

Human mycoses are caused by true fungal pathogens and opportunistic pathogens. Mycoses range from merely annoying (e.g. athlete's foot) to life-threatening (e.g., invasive aspergillosis). Pathogenicity of a fungus depends on its ability to adapt to the tissue environment and to withstand the lytic activity of the host's defenses [2] [7]. There are many metabolites produced by pathogenic fungi involving in mycoses. These metabolites are enzymes, siderophores, pigments and others.

\subsection{Extracellular Enzymes}

Fungi can produce and release several hydrolytic enzymes such as proteinases, lipases and phospholipases in culture media. These enzymes play a key role in fungal metabolism and may be involved in fungal pathogenesis, causing damage to the host tissues and providing nutrients in a restricted environment [133]. Production of proteinases, phospholipases and lipases by dermatophytes, C. albicans, A. fumigatus and C. neoformans is considered to be the fungal-associated factor that helps fungi in nutrient uptake, tissue invasion, adherence, dissemi- 
nation inside the host, overcoming the host immune system and strongly contribute to fungal pathogenicity [134]. Table 2 lists the major enzymes contributing the fungal pathogenicity. Dermatophytes produce proteinases such as keratinase and elastase playing important role in the pathogenicity of these fungi through keratin damage and elastin destruction due to secretion of two enzymes, respectively [2]. Endospores of Coccidioides immitis secrete proteinases with elastase and collagenase activity. These enzymes were found in culture filtrates of fungus and might play an essential role in the pathogenesis of coccidioidomycosis [135]. Proteinase-deficient strains of Candida albicans are non-invasive [136], and the pattern of adherence also reflects the expression of secretory proteinase [137]. Salivary proteins, including IgA, can be almost completely degraded by acidic proteinases called aspartic proteinases (Saps) of this yeast especially under low $\mathrm{pH}$ conditions [138]. Therefore, aspartic proteinases are of particular interest as virulence factors in the pathogenesis of Candida infections [139]-[141]. Hube and Naglik [142] demonstrated the production of Sap1-8 proteinases during oral and vaginal candidiasis. The results indicated that Sap1, Sap3, Sap4, Sap7 and Sap8 expression was correlated with oral disease, whereas Sap1, Sap3 and Sap6-8 expression was correlated with vaginal disease. Aspartic proteinase production is increased by $C$. albicans isolated from later stages of HIV infection and may contribute to candidosis [143]. A. fumigatus also secretes an aspartic proteinase (aspergillopepsin F) that can catalyze hydrolysis of the major structural proteins of basement membrane, elastin, collagen and laminin in the lung of a host [144]. By the immunogold electron microscopy, these authors showed that the aspartic proteinase was secreted by $A$. fumigatus invading neutropenic mouse lung and its secretion was directed toward the germ tubes of penetrating hyphae.

Extracellular phospholipase exhibits phospholipase B, lysophospholipase and lysophospholipase transacylase activities [145]. This enzyme can result in destabilization and destruction of the membranes and lung surfactant, cell lysis and release of lipid second messengers [146] [147]. Also, this enzyme enhances the adhesion of $C$. neoformans cells to the lung epithelium [148]. Lipase is another enzyme associated with the pathogenicity of Malassezia furfur that cause pityriasis versicolor. This association is showed by studies of Neves et al. [149] on

Table 2. Enzymes produced by some pathogenic fungi and their roles in pathogenesis.

\begin{tabular}{|c|c|c|}
\hline Enzyme & Fungal pathogen & Role in pathogenesis \\
\hline \multirow[t]{2}{*}{ Elastase } & Dermatophytes & Destruction of elastin in tissues \\
\hline & Coccidioides immitis & Destruction of elastin in lung and blood vessels \\
\hline Collagenase & C. immitis & Break the peptide bonds in collagen. \\
\hline Elastase-alkaline serine proteinase & Aspergillus fumigatus & Degradation of elastin in lung tissues \\
\hline Keratinase & Dermatophytes & Damage of keratin in epidermis of the skin \\
\hline Aspartic proteinase & $\begin{array}{l}\text { Candida albicans C. tropicalis } \\
\text { C. parapsilosis C. lusitaniae } \\
\text { A. fumigatus } \\
\text { Cryptococcus neoformans }\end{array}$ & $\begin{array}{c}\text { Destroying cell membranes and degrading host } \\
\text { surface molecules contributing host tissue invasion } \\
\text { and dissemination }\end{array}$ \\
\hline Phospholipase & $\begin{array}{c}\text { Dermatophytes Aspergillus spp. } \\
\text { C. neoformans C. albicans } \\
\text { Trichophyton rumrum } \\
\text { Microsporum canis } \\
\text { Fonsecaea pedrosoi }\end{array}$ & $\begin{array}{l}\text { Cleavage of phosphodiester bond in membrane lipids } \\
\text { for invasion }\end{array}$ \\
\hline Lipase & $\begin{array}{c}\text { Malassezia furfur F. pedrosoi } \\
\text { Phialophora verrucosa } \\
\text { Cladosporium carrionii } \\
\text { Cladophialophora bantiana } \\
\text { Exophiala jeanselmei }\end{array}$ & Degradation of lipids on the skin \\
\hline Catalase & $\begin{array}{l}\text { Aspergillus spp. Histoplasma } \\
\text { capsulatum C. albicans }\end{array}$ & Protection from oxidative killing in macrophages \\
\hline Superoxide dismutase & Aspergillus spp. C. albicans & Prevention from oxidative damage in macrophages \\
\hline Urease & $\begin{array}{l}\text { C. neoformans, } F \text {. pedrosoi } \\
P . \text { verrucosa, } C \text {. carrionii } \\
\text { C. bantiana, E. jeanselmei }\end{array}$ & Hydrolysis of urea to carbon dioxide and ammonia \\
\hline
\end{tabular}


fungal isolates from human healthy skin and with macules. Cryptococcal invasion of the central nervous system may be facilitated by urease production. Olszewski et al. [150] suggested that urease production by $C$. neoformans facilitates blood capillaries sequestration and disruption of endothelial cells and, in consequence, crossing the blood-brain barrier via a paracellular mechanism. C. neoformans is also able to acquire iron from its environment during host infection via enzymatic system. The production of urease also shows a positive correlation with the pathogenicity of other fungal agents causing diseases in humans, such as C. immitis [151] and P. brasiliensis [152].

A recent study demonstrated that $C$. neoformans was able to secrete vesicles containing many of enzymes, including laccase, urease and phospholipase B [153]. During disseminated cryptococcosis, measurable levels of cryptococcal products are detected in the body fluid of patients [154], suggesting that these vesicles may represent an efficient and general way of delivering pathogenesis-related metabolites to the extracellular environment by C. neoformans [153]. Dimorphism is a fungal characteristic which depends on alteration of body temperature, osmotic stress, oxidative stress and certain human hormones and helping the fungus to withstand the aggression by the host. Dimorphism-regulating histidine kinase enzyme in dimorphic molds such as Histoplasma capsulatum, Blastomyces dermatitidis and C. immitis can cause them to switch from their non-virulent mold forms to their virulent yeast forms. It also triggers the yeast $C$. albicans to switch from its yeast form to its more virulent hyphal form [2]. In iron gathering, $C$. neoformans and $H$. capsulatum reduce ferric to ferrous with a ferric reductase present at the fungal cell surface. This process is followed by transport of the ferrous ions into the cell by a permease and ferroxidase complex connected with the plasma membrane and ultimately enhancing fungal growth [155] [156]. To overcome the host defense mechanism, superoxide dismutase and catalase are produced by C. albicans [157] and A. fumigatus [158] when exposed to reactive oxygen species produced by phagocytic cells.

\subsection{Siderophores (Iron Chelators)}

Iron element is required for growth of the vast majority of microorganisms, because it serves as a catalytic cofactor in oxidation-reduction reactions [159] [160]. In the aerobic environments, iron exists mainly as Fe (III) and tends to form insoluble hydroxides and oxyhydroxides [160] [161], making it largely unavailable to fungi. In the human body, the majority of iron is bound up in hemoglobin, though other proteins bind iron directly, including transferrin, lactoferrin and ferritin, so the free iron concentration is extremely low insufficient for fungal growth [160]. Therefore, fungi need mechanisms to solubilize Fe(III) to make it available for uptake. These mechanisms usually involve the production of siderophores. Siderophores are low molecular weight (500 - 1000 $\mathrm{Da}$ ), high affinity ferric iron-chelating compounds produced by all microorganisms including fungi, with the exception of Saccharomyces spp. and obligate anaerobic bacteria which do not produce them [8] [162], although Saccharomyces cerevisiae and some pathogenic yeasts (e.g. Cryptococcus neoformans and C. albicans) can use exogenous siderophores [163]. Siderophores are very important to solubilize and transport inorganic iron [164]. In comparison with bacterial siderophores containing a variety of functional groups [165], most fungi produce hydroxamate-type siderophores [8] [166]. However, the zygomycetes form iron-regulated polycarboxylates [167], and there are well-documented reports of phenolate-catecholates in species of the wood-rotting fungi [168]. The mechanisms of fungal pathogenesis are much less-well understood than are those of bacterial pathogens [169]. Recent reports show that iron plays an important role in the virulence of pathogenic fungi [170] [171]. Because fungal iron supply systems are crucial in overcoming the iron shortage imposed by the host, most fungi express specific mechanisms for the acquisition of iron from the hosts they infect for their own survival [172]. Recently, siderophore biosynthesis has been found to be crucial for fungal pathogenicity [173]. Siderophores secreted by pathogenic fungi are critical for their survival in mammalian hosts whose iron homeostasis is strictly regulated [174]. They have biosynthesized by many human pathogens such as Cryptococcus neoformans [155], H. capsulatum [166] [175], Aspergillus fumigatus [176] [177], B. dermatitidis, Sporothrix schenickii, C. albicans and Trichophyton mentagrophytes [166], and are essential for virulence in host-fungus interactions. In addition to transporting iron and pathogenicity, siderophores have other functions and effects, including, acting as intracellular iron storage compounds, thereby preventing the formation of free radicals which are formed by unbound iron [8] [178] and suppressing growth of other microorganisms [8]. Fungal-siderophores structures, their functions and applications are well reviewed by Renshaw et al. [8]. 


\subsubsection{Hydroxamates}

Other than zygomycetes, most ascomycetous and basidomycetous fungi can synthesize hydroxamate-type siderophores containing $N^{5}$-hydroxy- $N^{5}$-acyl-L-ornithine residues as a basic structural units which constitute the iron binding ligands [179]. Virtually all of the fungal hydroxamate siderophores characterized so far are derived from L-ornithine and biosynthesis of siderophores is regulated by an internal iron-sensing mechanism [8]. Fungal hydroxamates can be divided into three structural categories: fusarinines, coprogens and ferrichromes. Each hydroxamate groups provides two oxygen molecules, which form a bidentate ligand with iron.

1) Fusarinines

Fusarinines are either linear (dimers or trimmers) or cyclic trimers hydroxamates in which $N$-hydroxyornithine is $N$ acylated by anhydromevalonic acid [180] [181]. Except neurosporin, fusarinines are made of cis-fusarinine units [182]. The monomers cis- and trans-fusarinine are the structural units of a large number of fungal siderophores [182]. There are three types of fusarinines, fusarinine A (linear dimers), fusarinine B (linear trimers) and fusarinine $\mathrm{C}$ (cyclic trimmers, also called fusigen) [8]. Among zoopathogenic fungi, various fusarinines are found in H. capsulatum [183], Paecilomyces spp., Aspergillus spp., Fusarium spp. [180] and Epicoccum purpurescens [184].

2) Coprogens

Coprogens are linear dihydroxamate and trihydroxamate ligands composed of trans-fusarinine units [185]. They are produced by H. capsulatum [183], B. dermatitidis [186], Fusarium dimerum and Curvularia lunata [180].

\section{3) Ferrichromes}

Ferrichromes are cyclic peptides containing $N$ - $\delta$-acyl- $N$ - $\delta$-hydroxyornithine and combinations of glycine, serine or alanine. They are the most common fungal siderophores [187], and produced by Trichophyton spp. [188], Microsporum spp. [188] [189] and Aspergillus spp. [180] [185]. In addition to their roles in iron solubilization and transporting, ferrichromes are intracellular iron storage molecules.

\subsubsection{Carboxylates}

Although most of the fungal siderophores are hydroxamates, a new carboxylate siderophore, rhizoferrin, has been detected [190]. Rhizoferrin functions as the main siderophore of the Zygomycetes. Its production, isolation and structure have described by Drechsel et al. [191]. Zygomycosis (also called mucormycosis) is a fungal infection caused by fungi belonging to Zygomycetes. In this context, zygomycosis may be associated with rhizoferrin production. Therefore and to show this association, further studies are required.

\section{Pigments}

\subsection{Melanins}

Melanins (Figure 8) are negatively charged, hydrophobic darkly pigmented polymers (brown or black in color) formed by oxidative polymerization of phenolic or indolic compounds [192]-[194]. The phenolic compounds from which the fungal melanins are derived include tyrosine via 3, 4-dihydroxyphenylalanine (DOPA) in various fungi and other microorganisms, $\gamma$-glutaminyl-3,4-dihydroxybenzene or catechol in basidiomycetes and 1,8-dihydroxynaphthalene (DHN) in ascomycetes and related deuteromycetes [195]. Melanins are made by several pathogenic fungi with several different types, but the two most important types are DHN (1,8-dihydroxynaphthalene) and DOPA (3,4-dihydroxyphenylalanine) melanins, which have been implicated in pathogenesis [194] [196] [197]. Fungal melanins are usually found in the cell walls of spores, sclerotia, mycelia or fruiting bodies [198]. Even when not directly involved in pathogenesis, melanins provide structural strength [199] and protect fungi against environmental stresses such as oxygen free radicals [200], UV radiation [201]-[204], wall-degrading enzymes produced by antagonist microbes [205] [206], high salinity [207] and heavy metals toxicity [208]. It has been suggested that due to antioxidant property of melanins they can neutralize oxidants produced by immune effector cells. Phagocytic leukocytes kill pathogenic microorganisms with a flux of secreted strong oxidants [209]. Thus, any microbial product which neutralizes oxidants is likely to protect the pathogen and promote invasion. Within the human body, fungal melanins can neutralize antimicrobial oxidants generated by immune effector cells [210]. The pathogenic yeast Cryptococcus neoformans serves as an example of how melanin production increases virulence. Several types of evidence support the antioxidant role of melanin in this yeast [211]-[214], i.e. the interference of melanins with oxidative metabolism of phagocytosis making 


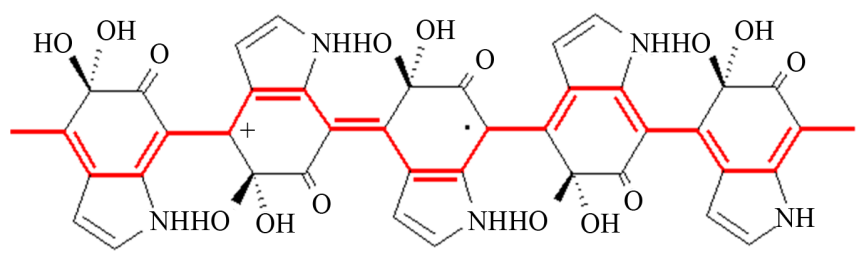

Figure 8. The chemical structure of melanin.

the fungus relatively resistant to leukocyte attack. The pathogenic roles for fungal melanins have been reviewed by Jacobson [194]. In addition to synthesis of melanin in vitro, some pathogenic fungi such as C. neoformans [215], Paracoccidioides brasiliensis [216] and C. albicans [217] can synthesize melanin during infection (in vivo), which has important implications for pathogenesis and antifungal drug development. Although much attention has been focused on the role of melanin in C. neoformans, this substance is constitutively produced in other pathogenic fungi in a group called dematiaceous fungi causing invasive disease called phaeohyphomycosis [218]. Dematiaceous fungi are a heterogeneous group of organisms unified by their production of melanin pigments [219]. The diseases caused by dematiaceous fungi have been reviewed by McGinnis et al. [220], Revankar [221] and Revankar et al. [222]. Due to protective role of fungal melanin, dematiceous fungi are extremely difficult to treat with antifungal drugs [223]. Table 3 lists the melanin-producing fungi which consist of both opportunistic and true pathogenic strains. As demonstrated by Cutler and Swatek [224], da Silva et al. [225], Dixon et al. [226], Jahn et al. [227] and Romero-Martinez et al. [200], melanins seem to be important in initiating an infection, because melanin-deficient (albino) fungi are much less infective.

\subsection{Carotenoids}

Carotenoids are a family of yellow to orange-red tetraterpenoid pigments synthesized by photosynthetic organisms, as well as many bacteria and fungi. They protect these organisms against photooxidation. They effectively quench singlet oxygen, i.e., they absorb energy from singlet oxygen $\left({ }^{1} \mathrm{O}_{2}\right)$ and convert it back into the unexcited ground state [228]. Carotenoids are produced by some pathogenic fungi such as the yeast Wangiella (Exophiala) dermatitidis that synthesizes, besides melanin, the carotenoids torulene (3,4-didehydro-g-carotene) and torularhodin (3,4-didehydro- $\beta, \gamma$-caroten-16-oic acid) [229]. As demonstrated by Geis and Szaniszlo [229], these carotenoids significantly increase post-UV irradiation survival rates of the melanin-deficient $W$. dermatitidis strain $\mathrm{Mel}^{-}$4. They suggested that the mechanism of carotenoid action is more likely to consist in shielding sensitive molecules or organelles rather than in neutralization of harmful oxidants. The influence of these carotenoids on the virulence of this yeast has also been studied by Schnitzler et al. [230]. They found that torulene and torularhodine were not contributed to the prevention of killing by neutrophils. Dixon et al. [226] [231] [232] observed a reduced virulence in mice when melanin- and carotenoids-deficient $W$. dermatitidis $8656\left(\mathrm{Mel}^{-} 3\right)$ strain was used, suggesting that the reduced virulence of this mutant is due to a lack of melanin and/or the carotenoids. Rhodotorula is a basidiomycetous yeast that produces mucoid colonies with a characteristic carotenoid pigment and is widely distributed in the environment. Although regarded as non-pathogenic, Rhodotorula species have emerged as opportunistic pathogens with the ability to colonize and infect susceptible patients. Most cases of Rhodotorula infection are fungemia associated with catheters, endocarditis and meningitis. Rhodotorula rubra is the most common cause of Rhodotorula species fungemia, followed by R. glutinis and R. minuta [233]. In general, there are very little information available concerning the involvement of carotenoids in fungal pathogenesis and further studies are required.

\section{Other Metabolites}

A number of other metabolites such as pullulan, mannitol, $\beta$-(1,3)-glucan, hem-binding proteins, estrogenbinding proteins and others could be a part of virulence factors contributing in fungal pathogenesis. These metabolites were listed in Table 4. Aureobasidium pullulans is potentially pathogenic yeast especially in immunocompromised patients [234]. Infections can range from subcutaneous to deep tissue. Severe infections have been noted such as in the serous membrane of the abdominal cavity [235] and in the spleen [236]. Niedoszytko et al. [237] concluded that sensitization to A pullulans is a risk factor for severe asthma. A. pullulans produces and se- 
Table 3. Melanin-producing fungi and related diseases.

\begin{tabular}{|c|c|}
\hline Fungus & Disease \\
\hline Aspergillus fumigatus $^{\mathrm{a}}$ & Invasive aspergillosis \\
\hline A. nidulans ${ }^{\mathrm{a}}$ & Invasive aspergillosis \\
\hline A. niger ${ }^{\mathrm{a}}$ & Invasive aspergillosis \\
\hline Alternaria alternate $^{\mathrm{a}}$ & Allergic reactions \\
\hline Alternaria tenuissima ${ }^{\mathrm{a}}$ & Cutaneous infection \\
\hline Aureobasidium pullulans ${ }^{\mathrm{a}}$ & Nosocomial infection asthma, peritonitis \\
\hline Bipolaris spicifera $^{\mathrm{a}}$ & Phaeohyphomycosis \\
\hline Blastomyces dermatitidis ${ }^{\mathrm{b}}$ & Blastomycosis \\
\hline Cladosporium carionii $^{\mathrm{b}}$ & Chromoblastomycosis \\
\hline Cryptococcus albidus $^{\mathrm{a}}$ & Cutaneous cryptococcosis \\
\hline C. laurentii ${ }^{\mathrm{a}}$ & Cutaneous cryptococcosis \\
\hline C. curvatus $^{\mathrm{a}}$ & Cryptococcosis \\
\hline C. neoformans ${ }^{\mathrm{a}}$ & Pulmonary cryptococcosis \\
\hline C. gattii $^{\mathrm{a}}$ & Cryptococcosis \\
\hline Dactylaria gallopava $^{\mathrm{a}}$ & Cerebral phaeohyphomycosis \\
\hline Exophiala jeanselmei $^{\mathrm{a}}$ & Subcutaneous phaeohyphomycosis \\
\hline Fonsecaea compacta $^{\mathrm{a}}$ & Chromoblastomycosis \\
\hline Fonsecaea pedrosoi $^{\mathrm{a}}$ & Chromoblastomycosis \\
\hline Histoplasma capsulatum $^{\mathrm{b}}$ & Histoplasmosis \\
\hline Paracoccidioides brasiliensis $^{\mathrm{b}}$ & Paracoccidioidomycosis \\
\hline Penicillium marneffei ${ }^{\mathrm{a}}$ & Penicilliosis \\
\hline Hortaea werneckii ${ }^{\mathrm{b}}$ & Tinea nigra \\
\hline Phialophora richardsiae ${ }^{\mathrm{a}}$ & Subcutaneous infections \\
\hline Scytalidium dimidiatum ${ }^{\mathrm{a}}$ & Skin and nail infections \\
\hline Sporothrix schenckii ${ }^{\mathrm{b}}$ & Sporotrichosis \\
\hline Wangiella (Exophiala) dermatitidis ${ }^{\mathrm{a}}$ & Phaeohyphomycosis \\
\hline Xylohypha bantiana ${ }^{\mathrm{a}}$ & Cerebral phaeohyphomycosis \\
\hline Scedosporium prolificans ${ }^{\mathrm{a}}$ & Invasive and disseminated infections \\
\hline Lacazia loboi ${ }^{\mathrm{b}}$ & Lobomycosis \\
\hline Pneumocystis carinii ${ }^{\mathrm{a}}$ & Pneumonia \\
\hline
\end{tabular}

${ }^{\mathrm{a}}$ Means opportunistic pathogen; ${ }^{\mathrm{b}}$ Means true pathogens.

cretes the polysaccharide pullulan and other biomacromolecules [238]. These molecules may play important roles in mediating adhesion and attachment on host cells playing a critical role in infection. The dimorphism of some pathogenic fungi is related to the cell wall components.

In the mycelial form, there is a predominance of $\beta$-(1,3)-glucan, whereas in the yeast form the main polysaccharide is $\alpha$-(1,3)-glucan [13]. Studies carried out on P. brasiliensis isolates have suggested that $\alpha$ - $(1,3)$-glucan protects the fungus against digestive enzymes of the host phagocytes [239]. $\alpha$-(1,3)-glucan is also found in other 
Table 4. Some fungal metabolites, their source and their roles in pathogenesis.

\begin{tabular}{|c|c|c|}
\hline Metabolite & Fungus & Role in pathogenesis \\
\hline$\beta$-(1,3)-glucan & $\begin{array}{l}\text { Paracoccidioides brasiliensis } \\
\text { Blastomyces dermatitidis } \\
\text { Histoplasma capsulatum }\end{array}$ & $\begin{array}{l}\text { Protection the fungi against digestive } \\
\text { enzymes of the host phagocytes }\end{array}$ \\
\hline Mannitol & Cryptococcus neoformans & $\begin{array}{l}\text { Protection the fungi against oxidative } \\
\text { killing by host phagocytes }\end{array}$ \\
\hline Pullulan & Aureobasidium pullulans & Mediating adhesion and attachment on host cells \\
\hline Estrogen-binding proteins & Coccidioides immitis & $\begin{array}{l}\text { Accelerate spherule maturation and } \\
\text { endospore release }\end{array}$ \\
\hline Hem-binding proteins & Candida albicans & $\begin{array}{l}\text { Enabling the fungus to utilize hemin } \\
\text { and hemoglobin as iron sources. }\end{array}$ \\
\hline Agglutinin-like sequence (Als) proteins & C. albicans & Mediating adhesion on host cells \\
\hline Farnesol & C. albicans & Affect host immunity \\
\hline WI-1 protein & Blastomyces dermatitidis & Mediating adhesion on macrophages \\
\hline Glycoprotein (gp4) & P. brasiliensis & Mediating attachment on macrophages \\
\hline Glucuronoxylomannan (GXM) & $\begin{array}{l}\text { C. neoformans } \\
\text { Trichosporon beigelii }\end{array}$ & Immunosuppressive agent \\
\hline
\end{tabular}

pathogenic fungi such as $B$. dermatitidis and $H$. capsulatum, conferring higher rigidity to the cell wall and resistance to the attack of phagocytes [240] [241].

Mannitol is another metabolite which may be considered as virulence factor involved in fungal pathogenicity. Infection of the central nervous system caused by $C$. neoformans is often associated with production of a large amount of mannitol by this fungus [242]. This process may facilitate the development of meningoencephalitis, because mannitol increases the osmolality of the surrounding fluid, thus it may contribute to brain edema, and also prevents oxidative damage to the fungus [243]. Mannitol can protect the fungi from oxidative killing by neutrophils or by cell-free oxidants [244]. Mannitol production is also thought to be helpful for C. neoformans to resist other environmental stresses such as heat and osmotic stresses [245]. They showed that a C. neoformans mutant producing low levels of mannitol was more susceptible to heat and osmotic stresses.

C. albicans has plasma membrane-anchored proteins called hem-binding proteins enabling this fungus to utilize hemin and hemoglobin as iron sources. If these proteins are absent, iron metabolism in this fungus is severely affected [246]. In addition, the cell wall of this fungus has agglutinin-like sequence proteins (Als proteins) as adhesion molecules. By these proteins $C$. albicans has flexibility and adaptability and can invade different environments in the host [247]. A protein called WI-1 present on the surface of B. dermatitidis plays the role of an adhesin and is believed to favor adherence of the fungus to macrophages [248]. The surface glycoprotein (gp43) of $P$. brasiliensis seems to be related to the fungal pathogenesis. It is the major laminin-binding protein helping the yeast form of this fungus in attachment to macrophages [249]. Other adhesion molecules were reviewed by [134].

In iron limitation, C. neoformans, beside to ferric reductase, also secretes 3-hydroxyanthranilic acid which reduces ferric to ferrous for transport by a copper oxidase permease system [250]. Therefore, these metabolites play important roles in pathogenicity of this yeast.

Estrogen-binding proteins in the cytosol of $C$. immitis may represent virulence factors for this fungus. In this fungus these proteins accelerate spherule maturation and endospore release [2].

Farnesol is the first identified fungal and eukaryotic quorum sensing molecule. It is responsible for the regulation of yeast to mycelium conversion in C. albicans. Navarathna et al. [251] found that the cells programmed to secrete more farnesol were significantly more virulent than untreated C. albicans. With these findings, they concluded that the fungal quorum sensing molecule farnesol is a virulence attribute in candidiasis. They observed that farnesol altered the normal cytokine expression pattern in mice in a fashion favoring disease progression.

Navarathna et al. [252] concluded that farnesol inhibits the production of IL-12 p40 and p70 from IFN-gamma/LPS-stimulated macrophages. Therefore, the role of farnesol in systemic candidiasis is likely due to its ability to inhibit the critical Th1 cytokines IFN-gamma and IL-12 and perhaps to enhance a Th2 cytokine, IL-5. 
Glucuronoxylomannan (GXM) is the major component of Cryptococcus capsular polysaccharide (about $90 \%$ - 95\% of capsule), which represents an essential virulence factor that has multiple effects on host immunity [253]. In macrophages, C. neoformans releases GXM from its capsule during its replication and into vesicles around the phagosome of the host cell resulting in macrophage dysfunction and lysis [254]. Several publications have demonstrated that GXM has multiple effects. It shows potent immunosuppressive properties such as interference with neutrophil migration [255], interference with cytokine secretion [256], inhibition of T-cell proliferation [257], induction of macrophage apoptosis mediated by either Fas ligand [256] or by nitric oxide (NO) generation [253], induction of apoptosis in T cells [258] and delay maturation and activation of human dendritic cells [259]. In addition, high levels of GXM in the cerebrospinal fluid (CSF) can change the osmolarity of this fluid, thereby affecting its outflow and leading to increased intracranial pressure, headaches and visual disturbance [260].

A glucuronoxylomannan-like polysaccharide was detected in sera of patients with systemic infections caused by the opportunistic fungus Trichosporon beigelii through cross-reaction with anticryptococcal antibodies [261]. They found that pathogenic isolates from deep infections produced significantly more antigen than superficial or environmental isolates supporting the idea that this antigenic polysaccharide may be a virulence factor for this fungus.

The failure of phagocytes to interact with $T$. beigelii may be related to a surface component or components which restrict phagocyte-T. beigelii interaction [261].

\section{Conclusion}

According to the review of the literature on fungal mycopathy, it is clear that there are many metabolites with different roles in mycoses. All these metabolites make this eukaryotic group successful for the survival in a host thereby interacting and overcoming the host immune system. Some metabolites such as mycotoxins are reported widely and are of general concern, because they can cause mycotoxicoses in humans and animals. The sources and properties of these compounds have been highlighted in this review. Several extracellular enzymes such as proteases, lipases and phospholipases are very important virulence factors. These enzymes play a role in nutrition, tissue damage, dissemination within the human body, iron acquisition, overcoming the host defenses and strongly contribute to fungal pathogenicity. Iron chelating compounds (siderophores) are produced by many fungal pathogens to support their survival in mammalian hosts whose iron homeostasis is strictly regulated. Melanins are made by several pathogenic fungi with several different types and have been implicated in pathogenesis. They can neutralize oxidants produced by immune effector cells. Other fungal metabolites such as melanins, carotenoids and others as reviewed above were recorded to be virulence factors involved in fungal pathogenicity. We can conclude that the knowledge of the fungal pathogenicity and molecular basis of their virulence contributes in developing new strategies for treatment and new effective antifungal agents. Finally, the many properties of metabolites support a wide variety of functional models, and new and imaginative pathogenic hypotheses are needed.

\section{References}

[1] Garcia, D., Ramos, A.J., Sanchis, V. and Marin, S. (2009) Predicting Mycotoxins in Foods: A Review. Food Microbiology, 26, 757-769. http://dx.doi.org/10.1016/j.fm.2009.05.014

[2] Khan, M., Ahmad, I., Aqil, F., Owais, M., Shahid, M. and Musarrat, J. (2010) Virulence and Pathogenicity of Fungal Pathogens with Special Reference to Candida albicans. In: Ahmad, I., Owais, M., Shahid, M. and Aqil, F., Eds., Combating Fungal Infections: Problems and Remedy, Springer, Berlin Heidelberg, 21-45. http://dx.doi.org/10.1007/978-3-642-12173-9 2

[3] Keller, N.P., Turner, G. and Bennett, J.W. (2005) Fungal Secondary Metabolism—From Biochemistry to Genomics. Nature Reviews Microbiology, 3, 937-947. http://dx.doi.org/10.1038/nrmicro1286

[4] Yu, J.H. and Keller, N. (2005) Regulation of Secondary Metabolism in Filamentous Fungi. Annual Review of Phytopathology, 43, 437-458. http://dx.doi.org/10.1146/annurev.phyto.43.040204.140214

[5] Calvo, A.M., Wilson, R.A., Bok, J.W. and Keller, N.P. (2002) Relationship between Secondary Metabolism and Fungal Development. Microbiology and Molecular Biology Reviews, 66, 447-459. http://dx.doi.org/10.1128/MMBR.66.3.447-459.2002

[6] Fox, E.M. and Howlett, B.J. (2008) Secondary Metabolism: Regulation and Role in Fungal Biology. Current Opinion 
in Microbiology, 11, 481-487. http://dx.doi.org/10.1016/j.mib.2008.10.007

[7] Bennett, J.W. and Klich, M. (2003) Mycotoxins. Microbiology and Molecular Biology Reviews, 16, 497-516. http://dx.doi.org/10.1128/CMR.16.3.497-516.2003

[8] Renshaw, J.C., Robson, G.D., Trinci, A.P.J., Wiebe, M.G., Livens, F.R., Collison, D. and Taylor, R.J. (2002) Fungal siderophores: Structures, Functions and Applications. Mycological Research, 106, 1123-1142. http://dx.doi.org/10.1017/S0953756202006548

[9] Casadevall, A. (2007) Determinants of Virulence in the Pathogenic Fungi. Fungal Biology Reviews, 21, $130-132$. http://dx.doi.org/10.1016/j.fbr.2007.02.007

[10] Jand, S.K., Sharma, N.S. and Paviter, K. (2005) Mycoses and Mycotoxicosis in Poultry: A Review. The Indian Journal of Animal Sciences, 75, 465-476.

[11] Romani, L. (2004) Immunity to Fungal Infections. Nature Reviews Immunology, 4, 1-23. http://dx.doi.org/10.1038/nri1255

[12] Hogan, L.H. Klein, B.S. and Levitz, S.M. (1996) Virulence Factors of Medically Important Fungi. Clinical Microbiology Reviews, 9, 469-488.

[13] Kurokawa, C.S. Sugizaki, M.F. and Peracoli, M.T. (1998) Virulence Factors in Fungi of Systemic Mycoses. Revista do Instituto de Medicina Tropical de São Paulo, 40, 125-135. http://dx.doi.org/10.1590/S0036-46651998000300001

[14] Wolf-Hall, C. (2010) Fungal and Mushroom Toxins. In: Juneja, V.K. and Sofos, J.N., Eds., Pathogens and Toxins in Foods: Challenges and Interventions, ASM Press, Washington, 275-285.

[15] Heidtmann-Bemvenuti, R., Mendes, G.L., Scaglioni, P.T., Badiale-Furlong, E. and Souza-Soares, L.A. (2011) Biochemistry and Metabolism of Mycotoxins: A Review. African Journal of Food Science, 5, 861-869. http://dx.doi.org/10.5897/AJFSX11.009

[16] Jard, G., Liboz, T., Mathieu, F., Guyonvarc'h, A. and Lebrihi, A. (2011) Review of Mycotoxin Reduction in Food and Feed: From Prevention in the Field to Detoxification by Adsorption or Transformation. Food Additives \& Contaminants: Part A Chemistry, Analysis, Control, Exposure \& Risk Assessment, 28, 1590-1609.

[17] Moss, M.O. (1991) The Environmental Factors Controlling Mycotoxins Formation. In: Smith, J.E. and Anderson, R.A., Eds., Mycotoxins and Animal Foods, CRC Press, Boca Raton, 37-56.

[18] Urughucki, K. and Yamazahi, M. (1978) Toxicology, Biochemistry and Pathology of Mycotoxins. John Wiley \& Sons, Hoboken.

[19] Trucksess, M.W. and Scott, P.M. (2008) Mycotoxins in Botanicals and Dried Fruits: A Review. Food Additives \& Contaminants: Part A Chemistry, Analysis, Control, Exposure \& Risk Assessment, 25, 181-192.

[20] Paterson, R.R. and Lima, N. (2010) Toxicology of Mycotoxins. Molecular, Clinical and Environmental Toxicology, 100, 31-63. http://dx.doi.org/10.1007/978-3-7643-8338-1_2

[21] Bennett, J.W. (1987) Mycotoxins, Mycotoxicoses, Mycotoxicology and Mycopathologia. Mycopathologia, 100, 3-5. http://dx.doi.org/10.1007/BF00769561

[22] Gelderblom, W.A., Marasas, W.O., Vleggaar, R., Thiel, P. and Cawood, M.E. (1992) Fumonisins: Isolation, Chemical Characterization and Biological Effects. Mycopathologia, 117, 11-16. http://dx.doi.org/10.1007/BF00497273

[23] Geisen, R. and Schmidt-Heydt, M. (2009) Physiological and Molecular Aspects of Ochratoxin A Biosynthesis. In: Anke, T. and Weber, D., Eds., A Comprehensive Treatise on Fungi as Experimental Systems for Basic and Applied Research: Physiology and Genetics Selected Basic and Applied Aspects, Springer, Berlin Heidelberg, 353-376.

[24] CAST (Council for Agricultural Science and Technology) (2003) Mycotoxins: Risks in Plant, Animal, and Human Systems. Iowa, USA.

[25] Timbrell, J. (2002) Introduction to Toxicology. Taylor \& Francis, UK.

[26] Samson, R.A., Hoekstra, E.S., Frisvad, J.C. and Filtenborg, O. (1995) Introduction to Food-Borne Fungi. 4th Edition, Centraalbureau voor Schimmelcultures.

[27] Frisvad, J.C. and Samson, R.A. (2004) Emericella venezuelensis, a New Species with Stellate Ascospores Producing Sterigmatocystin and Aflatoxin B1. Systematic and Applied Microbiology, 27, 672-680. http://dx.doi.org/10.1078/0723202042369910

[28] Frisvad, J.C., Skouboe, P. and Samson, R.A. (2005) Taxonomic Comparison of Three Different Groups of Aflatoxin Producers and a New Efficient Producer of Aflatoxin B1, Sterigmatocystin and 3-O-Methylsterigmatocystin, Aspergillus rambellii sp. nov. Systematic and Applied Microbiology, 28, 442-453. http://dx.doi.org/10.1016/j.syapm.2005.02.012

[29] Klich, M.A., Cary, J.W., Beltz, S.B. and Bennett, C.A. (2003) Phylogenetic and Morphological Analysis of Aspergillus ochraceoroseus. Mycologia, 95, 1252-1260. http://dx.doi.org/10.2307/3761925 
[30] Ito, Y., Peterson, S.W., Wicklow, D.T. and Goto, T. (2001) Aspergillus pseudotamarii, a New Aflatoxin Producing Species in Aspergillus Section Flavi. Mycological Research, 105, 233-239. http://dx.doi.org/10.1017/S0953756200003385

[31] Pildain, M.B., Frisvad, J.C., Vaamonde, G., Cabral, D., Varga, J. and Samson, R.A. (2008) Two Novel AflatoxinProducing Aspergillus Species from Argentinean Peanuts. International Journal of Systematic and Evolutionary Microbiology, 58, 725-735.

[32] Varga, J., Frisvad, J.C. and Samson, R.A. (2011) Two New Aflatoxin Producing Species, and an Overview of Aspergillus Section Flavi. Studies in Mycology, 69, 57-80. http://dx.doi.org/10.3114/sim.2011.69.05

[33] Goldblatt, L.A. (1969) Aflatoxin: Scientific Background, Control, and Implications. Academic Press, New York.

[34] Cotty, P.J. and Jaime-Garcia, R. (2007) Influences of Climate on Aflatoxin Producing Fungi and Aflatoxin Contamination. International Journal of Food Microbiology, 119, 109-115.

[35] Gong, Y., Hounsa, A., Egal, S., Turner, P.C., Sutcliffe, A.E., Hall, A.J., Cardwell, K. and Wild, C.P. (2004) Postweaning Exposure to Aflatoxin Results in Impaired Child Growth: A Longitudinal Study in Benin, West Africa. Environmental Health Perspectives, 112, 1334-1338. http://dx.doi.org/10.1289/ehp.6954

[36] Wild, C.P. and Turner, P.C. (2002) The Toxicology of Aflatoxins as a Basis for Public Health Decisions. Mutagenesis, 17, 471-481. http://dx.doi.org/10.1093/mutage/17.6.471

[37] Williams, J.H., Phillips, T.D., Jolly, P.E., Stiles, J.K., Jolly, C.M. and Aggarwal, D. (2004) Human Aflatoxicosis in Developing Countries: A Review of Toxicology, Exposure, Potential Health Consequences, and Interventions. The American Journal of Clinical Nutrition, 80, 1106-1122.

[38] Kotsonis, F.N. and Burdock, G.A. (2008) Food Toxicology. In: Klaassen, C.D., Ed., Casarett and Doull's Toxicology: The Basic Science of Poisons, 7th Edition, McGraw-Hill, New York, 485-555.

[39] Weidenborner, M. (2001) Encyclopedia of Food Mycotoxins. Springer-Verlag, New York. http://dx.doi.org/10.1007/978-3-662-04464-3

[40] Squire, R.A. (1981) Ranking Animal Carcinogens: A Proposed Regulatory Approach. Science, 214, 877-880. http://dx.doi.org/10.1126/science.7302565

[41] Raj, H.G., Prasanna, H.R., Magee, P.N. and Lotlikar, P.D. (1986) Effect of Purified Rat and Hamster Hepatic Glutathione S-Transferases on the Microsome Mediated Binding of Aflatoxin B1 to DNA. Cancer Letters, 33, 1-9. http://dx.doi.org/10.1016/0304-3835(86)90095-9

[42] Verma, R.J. (2004) Aflatoxin Cause DNA Damage. International Journal of Human Genetics, 4, 231-236.

[43] Cole, R.J. and Cox, R.H. (1981) Handbook of Toxic Fungal Metabolites. Academic Press, New York.

[44] Grove, J.F. (2000) Non-Macrocyclic Trichothecenes Part 2. Progress in the Chemistry of Organic Natural Products, 69, 1-70.

[45] Scott, P.M. (1989) The Natural Occurrence of Trichothecenes. In: Beasley, V.H., Ed., Trichothecene Mycotoxicosis: Pathophysiologic Effects, CRC Press, Boca Raton, 1-26.

[46] Yazar, S. and Omurtag, G.Z. (2008) Fumonisins, Trichothecenes and Zearalenone in Cereals. International Journal of Molecular Sciences, 9, 2062-2090. http://dx.doi.org/10.3390/ijms9112062

[47] Chu, F.S. (1998) Mycotoxins-Occurrence and Toxic Effect. In: Sadler, M., Strain, J.J. and Caballero, B., Eds., Encyclopedia of Human Nutrition, Academic Press, New York, 858-869.

[48] Pestka, J.J. (2007) Deoxynivalenol: Toxicity, Mechanisms and Animal Health Risks. Animal Feed Science and Technology, 137, 283-298. http://dx.doi.org/10.1016/j.anifeedsci.2007.06.006

[49] Eriksen, G.S. and Pettersson, H. (2004) Toxicological Evaluation of Trichothecenes in Animal Feed. Animal Feed Science and Technology, 114, 205-239. http://dx.doi.org/10.1016/j.anifeedsci.2003.08.008

[50] Sokolovic, M., Garaj-Vrhovac, V. and Simpraga, B. (2008) T-2 Toxin: Incidence and Toxicity in Poultry. Arhiv za Higijenu Rada i Toksikologiju, 59, 43-52. http://dx.doi.org/10.2478/10004-1254-59-2008-1843

[51] Burck, W.B. and Cote, L.-M. (1991) Trichothecene Mycotoxins. In: Keeler, R.F. and Tu, A.T., Eds., Handbook of Natural Toxins: Toxicology of Plant and Fungal Compounds, Marcel Dekker, New York, 523-555.

[52] Wannemacher Jr., R.W., Bunner, D.L. and Neufeld, H.A. (1991) Toxicity of Trichothecenes and Other Related Mycotoxins in Laboratory Animals. In: Smith, J.E. and Henderson, R.S., Ed., Mycotoxins and Animal Foods, CRC Press, Boca Raton, 499-552.

[53] Zhou, H.-R., Islam, Z. and Pestka, J.J. (2005) Induction of Competing Apoptotic and Survival Signaling Pathways in the Macrophage by the Ribotoxic Trichothecene Deoxynivalenol. Toxicological Sciences, 87, 113-122. http://dx.doi.org/10.1093/toxsci/kfi234

[54] Sergent, T., Parys, M., Garsou, S., Pussemier, L., Schneider, Y.-J. and Larondelle, Y. (2006) Deoxynivalenol Transport 
across Human Intestinal Caco-2 Cells and Its Effects on Cellular Metabolism at Realistic Intestinal Concentrations. Toxicology Letters, 164, 167-176. http://dx.doi.org/10.1016/j.toxlet.2005.12.006

[55] Kankkunen, P., Rintahaka, J., Aalto, A., Leino, M., Majuri, M.L., Alenius, H., Wolff, H. and Matikainen, S. (2009) Trichothecene Mycotoxins Activate Inflammatory Response in Human Macrophages. The Journal of Immunology, 182, 6418-6425. http://dx.doi.org/10.4049/jimmunol.0803309

[56] Ammann, H.M. (2003) Is Indoor Mold Contamination a Threat to Health? Part Two. Journal of Environmental Health, 66, 47-49.

[57] Nielsen, K.F. (2003) Mycotoxin Production by Indoor Molds. Fungal Genetics and Biology, 39, 103-117. http://dx.doi.org/10.1016/S1087-1845(03)00026-4

[58] Sudakin, D.L. (2003) Trichothecenes in the Environment: Relevance to Human Health. Toxicology Letters, 143, 97107. http://dx.doi.org/10.1016/S0378-4274(03)00116-4

[59] Middlebrook, J.L. and Leatherman, D.L. (1989) Binding of T-2 Toxin to Eukaryotic Cell Ribosomes. Biochemical Pharmacology, 38, 3103-3110. http://dx.doi.org/10.1016/0006-2952(89)90021-X

[60] Ueno, Y., Iijima, K., Wang, S.D., Sugiura, Y., Sekijima, M., Tanaka, T., Chen, C. and Yu, S.Z. (1997) Fumonisins as a Possible Contributory Risk Factor for Primary Liver Cancer: A 3-Year Study of Corn Harvested in Haimen, China, by HPLC and ELISA. Food and Chemical Toxicology, 35, 1143-1150. http://dx.doi.org/10.1016/S0278-6915(97)00113-0

[61] Bae, H.K., Shinozuka, J., Islam, Z. and Pestka, J.J. (2009) Satratoxin G Interaction with 40S and 60S Ribosomal Subunits Precedes Apoptosis in the Macrophage. Toxicology and Applied Pharmacology, 237, 137-145. http://dx.doi.org/10.1016/j.taap.2009.03.006

[62] Islam, Z., Amuzie, C.J., Harkema, J.R. and Pestka, J.J. (2007) Neurotoxicity and Inflammation in the Nasal Airways of Mice Exposed to the Macrocyclic Trichothecene Mycotoxin Roridin A: Kinetics and Potentiation by Bacterial Lipopolysaccharide Coexposure. Toxicological Sciences, 98, 526-541. http://dx.doi.org/10.1093/toxsci/kfm102

[63] Laskin, J.D., Heck, D.E. and Laskin, D.L. (2002) The Ribotoxic Stress Response as a Potential Mechanism for MAP Kinase Activation in Xenobiotic Toxicity. Toxicological Sciences, 69, 289-291. http://dx.doi.org/10.1093/toxsci/69.2.289

[64] Pestka, J.J. (2008) Mechanisms of Deoxynivalenol-Induced Gene Expression and Apoptosis. Food Additives \& Contaminants: Part A Chemistry, Analysis, Control, Exposure \& Risk Assessment, 25, 1128-1140.

[65] Anli, E. and Alkis, İ.M. (2010) Ochratoxin A and Brewing Technology: A Review. Journal of the Institute of Brewing, 116, 23-32. http://dx.doi.org/10.1002/j.2050-0416.2010.tb00394.x

[66] Varga, J., Kocsube, S., Peteri, Z., Vagvolgyi, C. and Toth, B. (2010) Chemical, Physical and Biological Approaches to Prevent Ochratoxin Induced Toxicoses in Humans and Animals. Toxins (Basel), 2, 1718-1750. http://dx.doi.org/10.3390/toxins2071718

[67] Li, S., Marquardt, R.R., Frohlich, A.A., Vitti, T.G. and Crow, G. (1997) Pharmacokinetics of Ochratoxin A and Its Metabolites in Rats. Toxicology and Applied Pharmacology, 145, 82-90. http://dx.doi.org/10.1006/taap.1997.8155

[68] Reddy, L. and Bhoola, K. (2010) Ochratoxins-Food Contaminants: Impact on Human Health. Toxins (Basel), 2, 771779. http://dx.doi.org/10.3390/toxins2040771

[69] Van Der Merwe, K.J., Steyn, P.S., Fourie, L., Scott, D.B. and Theron, J.J. (1965) Ochratoxin A, a Toxic Metabolite Produced by Aspergillus ochraceus Wilh. Nature, 205, 1112-1113. http://dx.doi.org/10.1038/2051112a0

[70] Petzinger, E. and Ziegler, K. (2000) Ochratoxin A from a Toxicological Perspective. Journal of Veterinary Pharmacology and Therapeutics, 23, 91-98. http://dx.doi.org/10.1046/j.1365-2885.2000.00244.x

[71] Dirheimer, G. and Creppy, E.E. (1991) Mechanism of Action of Ochratoxin A. IARC Scientific Publications, 115, 171-186.

[72] Hohler, D. (1998) Ochratoxin A in Food and Feed: Occurrence, Legislation and Mode of Action. Z Ernahrungswiss, 37, 2-12.

[73] Marquardt, R.R. and Frohlich, A.A. (1992) A Review of Recent Advances in Understanding Ochratoxicosis. Journal of Animal Science, 70, 3968-3988.

[74] Meisner, H. and Meisner, P. (1981) Ochratoxin A, an in Vivo Inhibitor of Renal Phosphoenolpyruvate Carboxykinase. Archives of Biochemistry and Biophysics, 208, 146-153. http://dx.doi.org/10.1016/0003-9861(81)90133-8

[75] Rahimtula, A.D., Bereziat, J.C., Bussacchini-Griot, V. and Bartsch, H. (1988) Lipid Peroxidation as a Possible Cause of Ochratoxin A Toxicity. Biochemical Pharmacology, 37, 4469-4477. http://dx.doi.org/10.1016/0006-2952(88)90662-4

[76] Hult, K., Pleština, R., Habazin-Novak, V., Radić, B. and Čeović, S. (1982) Ochratoxin A in Human Blood and Balkan Endemic Nephropathy. Archives of Toxicology, 51, 313-321. http://dx.doi.org/10.1007/BF00317010

[77] Krogh, P. (1987) Ochratoxin in Foods. In: Krogh, P., Ed., Mycotoxins in Food, Academic Press, London, 97-110. 
[78] Puntaric, D., Bosnir, J., Smit, Z., Skes, I. and Baklaic, Z. (2001) Ochratoxin A in Corn and Wheat: Geographical Association with Endemic Nephropathy. Croatian Medical Journal, 42, 175-180.

[79] Voss, K.A., Smith, G.W. and Haschek, W.M. (2007) Fumonisins: Toxicokinetics, Mechanism of Action and Toxicity. Animal Feed Science and Technology, 137, 299-325. http://dx.doi.org/10.1016/j.anifeedsci.2007.06.007

[80] Frisvad, J.C., Smedsgaard, J., Samson, R.A., Larsen, T.O. and Thrane, U. (2007) Fumonisin B2 Production by Aspergillus niger. Journal of Agricultural and Food Chemistry, 55, 9727-9732. http://dx.doi.org/10.1021/jf0718906

[81] Bartok, T., Szecsi, A., Szekeres, A., Mesterhazy, A. and Bartok, M. (2006) Detection of New Fumonisin Mycotoxins and Fumonisin-Like Compounds by Reversed-Phase High-Performance Liquid Chromatography/Electrospray Ionization Ion Trap Mass Spectrometry. Rapid Communications in Mass Spectrometry, 20, 2447-2462. http://dx.doi.org/10.1002/rcm.2607

[82] Gelderblom, W.C.A., Cawood, M.E, Snyman, S.D., Vleggaar, R. and Marasas, W.F.O. (1993) Structure-Activity Relationships of Fumonisins in Short-Term Carcinogenesis and Cytotoxicity Assays. Food and Chemical Toxicology, 31, 407-414. http://dx.doi.org/10.1016/0278-6915(93)90155-R

[83] Marasas, W.F. (2001) Discovery and Occurrence of the Fumonisins: A Historical Perspective. Environmental Health Perspectives, 109, 239-243.

[84] Marasas, W.F., Riley, R.T., Hendricks, K.A., Stevens, V.L., Sadler, T.W., Gelineau-van Waes, J., Missmer, S.A., Cabrera, J., Torres, O., Gelderblom, W.C., Allegood, J., Martinez, C., Maddox, J., Miller, J.D., Starr, L., Sullards, M.C., Roman, A.V., Voss, K.A., Wang, E. and Merrill Jr., A.H. (2004) Fumonisins Disrupt Sphingolipid Metabolism, Folate Transport, and Neural Tube Development in Embryo Culture and in Vivo: A Potential Risk Factor for Human Neural Tube Defects among Populations Consuming Fumonisin-Contaminated Maize. Journal of Nutrition, 134, 711-716.

[85] Riley, R.T., Wang, E., Schroeder, J.J., Smith, E.R., Plattner, R.D., Abbas, H., Yoo, H.S. and Merrill Jr., A.H. (1996) Evidence for Disruption of Sphingolipid Metabolism as a Contributing Factor in the Toxicity and Carcinogenicity of Fumonisins. Natural Toxins, 4, 3-15. http://dx.doi.org/10.1002/19960401NT2

[86] Missmer, S.A., Suarez, L., Felkner, M., Wang, E., Merrill Jr., A.H., Rothman, K.J. and Hendricks, K.A. (2006) Exposure to Fumonisins and the Occurrence of Neural Tube Defects along the Texas-Mexico Border. Environmental Health Perspectives, 114, 237-241. http://dx.doi.org/10.1289/ehp.8221

[87] Fincham, J.E., Marasas, W.F., Taljaard, J.J., Kriek, N.P., Badenhorst, C.J., Gelderblom, W.C., Seier, J.V., Smuts, C.M., Faber, M., Weight, M.J., Slazus, W., Woodroof, C.W., van Wyk, M.J., Marita, K., Thiel, P.G. (1992) Atherogenic Effects in a Non-Human Primate of Fusarium moniliforme Cultures Added to a Carbohydrate Diet. Atherosclerosis, 94, 13-25. http://dx.doi.org/10.1016/0021-9150(92)90183-H

[88] Kim, Y.T., Lee, Y.R., Jin, J., Han, K.H., Kim, H., Kim, J.C., Lee, T., Yun, S.H. and Lee, Y.W. (2005) Two Different Polyketide Synthase Genes Are Required for Synthesis of Zearalenone in Gibberella zeae. Molecular Microbiology, 58, 1102-1113. http://dx.doi.org/10.1111/j.1365-2958.2005.04884.x

[89] Glenn, A.E. (2007) Mycotoxigenic Fusarium Species in Animal Feed. Animal Feed Science and Technology, 137, 213240. http://dx.doi.org/10.1016/j.anifeedsci.2007.06.003

[90] Hestbjerg, H., Nielsen, K.F., Thrane, U. and Elmholt, S. (2002) Production of Trichothecenes and Other Secondary Metabolites by Fusarium culmorum and Fusarium equiseti on Common Laboratory Media and a Soil Organic Matter Agar: An Ecological Interpretation. Journal of Agricultural and Food Chemistry, 50, 7593-7599. http://dx.doi.org/10.1021/jf020432o

[91] Mirocha, C.J., Pathre, S.V., Schauerhamer, B. and Christensen, C.M. (1976) Natural Occurrence of Fusarium Toxins in Feedstuff. Applied and Environmental Microbiology, 32, 553-556.

[92] Fink-Gremmels, J. and Malekinejad, H. (2007) Clinical Effects and Biochemical Mechanisms Associated with Exposure to the Mycoestrogen Zearalenone. Animal Feed Science and Technology, 137, 326-341. http://dx.doi.org/10.1016/j.anifeedsci.2007.06.008

[93] Sekiyama, B.L., Ribeiro, A.B., Machinski, P.A. and Machinski Jr., M. (2005) Aflatoxins, Ochratoxin A and Zearalenone in Maize-Based Food Products. Brazilian Journal of Microbiology, 36, 289-294. http://dx.doi.org/10.1590/S1517-83822005000300016

[94] Danicke, S., Swiech, E., Buraczewska, L. and Ueberschar, K.H. (2005) Kinetics and Metabolism of Zearalenone in Young Female Pigs. Journal of Animal Physiology and Animal Nutrition (Berl), 89, 268-276. http://dx.doi.org/10.1111/j.1439-0396.2005.00516.x

[95] Saenz de Rodriguez, C.A., Bongiovanni, A.M. and Conde de Borrego, L. (1985) An Epidemic of Precocious Development in Puerto Rican Children. Journal of Pediatrics, 107, 393-396. http://dx.doi.org/10.1016/S0022-3476(85)80513-8

[96] Painter, K. (1997) Puberty Signs Evident in 7- and 8-Year Old Girls. USA Today, 8 April, P.A-1.

[97] Meucci, V., Soldani, G., Razzuoli, E., Saggese, G. and Massart, F. (2011) Mycoestrogen Pollution of Italian Infant 
Food. Journal of Pediatrics, 159, 278-283. http://dx.doi.org/10.1016/j.jpeds.2011.01.028

[98] Bandera, E.V., Chandran, U., Buckley, B., Lin, Y., Isukapalli, S., Marshall, I., King, M. and Zarbl, H. (2011) Urinary Mycoestrogens, Body Size and Breast Development in New Jersey Girls. Science of the Total Environment, 409, 52215227. http://dx.doi.org/10.1016/j.scitotenv.2011.09.029

[99] Leffers, H., Naesby, M., Vendelbo, B., Skakkebaek, N.E. and Jorgensen, M. (2001) Oestrogenic Potencies of Zeranol, Oestradiol, Diethylstilboestrol, Bisphenol-A and Genistein: Implications for Exposure Assessment of Potential Endocrine Disrupters. Human Reproduction, 16, 1037-1045. http://dx.doi.org/10.1093/humrep/16.5.1037

[100] Shier, W.T., Shier, A.C., Xie, W. and Mirocha, C.J. (2001) Structure-Activity Relationships for Human Estrogenic Activity in Zearalenone Mycotoxins. Toxicon, 39, 1435-1438. http://dx.doi.org/10.1016/S0041-0101(00)00259-2

[101] Tiemann, U., Tomek, W., Schneider, F. and Vancelow, J. (2003) Effects of the Mycotoxins $\alpha$ - and $\beta$-Zearalenol on Regulation of Progesterone Synthesis in Cultured Granulose Cells from Porcine Ovaries. Reproductive Toxicology, 17, 673-681. http://dx.doi.org/10.1016/j.reprotox.2003.07.001

[102] Li, S.M., Wang, X.M., Qiu, J., Si, Q., Guo, H.Y., Sun, R.Y. and Wu, Q.X. (2005) Inhibitory Effects of Alpha-Zearalenol on Angiotensin II-Induced Integrin Beta3 mRNA via Suppression of Nuclear Factor-KappaB. Biomedical and Environmental Science, 18, 314-320.

[103] Okafor, N. (2007) Modern Industrial Microbiology and Bitechnology. Science Publishers, Enfield.

[104] Panaccione, D.G. and Coyle, C.M. (2005) Abundant Respirable Ergot Alkaloids from the Common Airborne Fungus Aspergillus fumigatus. Applied and Environmental Microbiology, 71, 3106-3111. http://dx.doi.org/10.1128/AEM.71.6.3106-3111.2005

[105] Schardl, C.L., Blankenship, J.D., Spierin, M.J. and Machado, C. (2004) Loline and Ergot Alkaloids in Grass Endo-Phytes. In: An, Z., Ed., Handbook of Industrial Mycology, Marcel Dekker, New York, 427-448.

[106] Bacon, C.W., Porter, J.K. and Robbins, J.D. (1979) Laboratory Production of Ergot Alkaloids by Species of Balansia. Journal of General Microbiology, 113, 119-126. http://dx.doi.org/10.1099/00221287-113-1-119

[107] Kozlovsky, A.G., Zhelifonova, V.P. and Antipova, T.V. (2005) The Fungus Penicillium citrinum, Isolated from Permafrost Sediments, as a Producer of Ergot Alkaloids and New Quinoline Alkaloids Quinocitrinines. Applied Biochemistry and Microbiology, 41, 499-502. http://dx.doi.org/10.1007/s10438-005-0090-9

[108] Scott, P.M. (2009) Ergot Alkaloids: Extent of Human and Animal Exposure. World Mycotoxin Journal, 2, $141-149$. http://dx.doi.org/10.3920/WMJ2008.1109

[109] Rigbers, O. and Li, S.M. (2008) Ergot Alkaloid Biosynthesis in Aspergillus fumigatus: Overproduction and Biochemical Characterization of a 4-Dimethylallyltryptophan N-Methyltransferase. The Journal of Biological Chemistry, 283, 26859-26868. http://dx.doi.org/10.1074/jbc.M804979200

[110] Machado, C. (2004) Studies of Ergot Alkaloid Biosynthesis Genes in Clavicipitaceous Fungi. Ph.D. Thesis, University of Kentucky, Kentucky.

[111] de Groot, A.N., van Dongen, P.W., Vree, T.B., Hekster, Y.A. and van Roosmalen, J. (1998) Ergot Alkaloids. Current Status and Review of Clinical Pharmacology and Therapeutic Use Compared with Other Oxytocics in Obstetrics and Gynaecology. Drugs, 56, 523-535.

[112] Bennett, J.W. and Bentley, R. (1999) Pride and Prejudice: The Story of Ergot. Perspectives in Biology and Medicine, 42, 333-355.

[113] Silberstein, S.D. and McCrory, D.C. (2003) Ergotamine and Dihydroergotamine: History, Pharmacology, and Efficacy. Headache, 43, 144-166. http://dx.doi.org/10.1046/j.1526-4610.2003.03034.x

[114] Manabe, M. (2001) Fermented Foods and Mycotoxins. Mycotoxins, 51, 25-28. http://dx.doi.org/10.2520/myco.51.25

[115] Blanc, P.J., Loret, M.O. and Goma, G. (1995) Production of Citrinin by Various Species of Monascus. Biotechnology Letters, 17, 291-294. http://dx.doi.org/10.1007/BF01190639

[116] Pattanagul, P., Pinthong, R., Phianmongkhol, A. and Tharatha, S. (2008) Mevinolin, Citrinin and Pigments of Adlay Angkak Fermented by Monascus sp. International Journal of Food Microbiology, 126, 20-23. http://dx.doi.org/10.1016/j.ijfoodmicro.2008.04.019

[117] Shimizu, T., Kinoshita, H., Ishihara, S., Sakai, K., Nagai, S. and Nihira, T. (2005) Polyketide Synthase Gene Responsible for Citrinin Biosynthesis in Monascus purpureus. Applied and Environmental Microbiology, 71, 3453-3457. http://dx.doi.org/10.1128/AEM.71.7.3453-3457.2005

[118] Kumar, M., Dwivedi, P., Sharma, A., Singh, N. and Patil, R. (2007) Ochratoxin A and Citrinin Nephrotoxicity in New Zealand White Rabbits: An Ultrastructural Assessment. Mycopathologia, 163, 21-30. http://dx.doi.org/10.1007/s11046-006-0079-9

[119] Chagas, G.M., Oliveira, M.B.M., Campello, A.P. and Kluppel, M.L.W. (1995) Mechanism of Citrinin-Induced Dysfunction of Mitochondria. IV-Effect on $\mathrm{Ca}^{2+}$ Transport. Cell Biochemistry and Function, 13, 53-59. 
http://dx.doi.org/10.1002/cbf.290130110

[120] Puel, O., Galtier, P. and Oswald, I. (2010) Biosynthesis and Toxicological Effects of Patulin. Toxins, 2, 613-631. http://dx.doi.org/10.3390/toxins2040613

[121] Wagener, R.E., Davis, N.D. and Diener, U.L. (1980) Penitrem A and Roquefortine Production by Penicillium commune. Applied and Environmental Microbiology, 39, 882-887.

[122] Moulé, Y., Jemmali, M. and Darracq, N. (1978) Inhibition of Protein Synthesis by PR Toxin, a Mycotoxin from Penicillium roqueforti. FEBS Letters, 88, 341-344. http://dx.doi.org/10.1016/0014-5793(78)80207-5

[123] Wei, R.D., Lee, W.Y.H. and Wei, Y.H. (1985) Some Bio-Chemical Responses to PR toxin, a Mycotoxin from Penicillium roqueforti. In: Lacey, J., Ed., Trichothecense and Other Mycotoxins, John Wiley \& Sons, Inc., New York, 337348.

[124] Duran, R.M., Cary, J.W. and Calvo, A.M. (2007) Production of Cyclopiazonic Acid, Aflatrem, and Aflatoxin by Aspergillus flavus Is Regulated by veA, a Gene Necessary for Sclerotial Formation. Applied Microbiology and Biotechnology, 73, 1158-1168. http://dx.doi.org/10.1007/s00253-006-0581-5

[125] Gupta, S., Krasnoff, S., Underwood, N., Renwick, J.A.A. and Roberts, D. (1991) Isolation of Beauvericin as an Insect Toxin from Fusarium semitectum and Fusarium moniliforme var. subglutinans. Mycopathologia, 115, 185-189. http://dx.doi.org/10.1007/BF00462223

[126] Logrieco, A., Moretti, A., Castella, G., Kostecki, M., Golinski, P., Ritieni, A. and Chelkowski, J. (1998) Beauvericin Production by Fusarium Species. Applied and Environmental Microbiology, 64, 3084-3088.

[127] Tomoda, H., Huang, X.H., Cao, J., Nishida, H., Nagao, R., Okuda, S., Tanaka, H., Omura, S., Arai, H. and Inoue, K. (1992) Inhibition of Acyl-CoA: Cholesterol Acyltransferase Activity by Cyclodepsipeptide Antibiotics. The Journal of Antibiotics, 45, 1626-1632. http://dx.doi.org/10.7164/antibiotics.45.1626

[128] Calo, L., Fornelli, F., Ramires, R., Nenna, S., Tursi, A., Caiaffa, M.F. and Macchia, L. (2004) Cytotoxic Effects of the Mycotoxin Beauvericin to Human Cell Lines of Myeloid Origin. Pharmacological Research, 49, 73-77. http://dx.doi.org/10.1016/j.phrs.2003.07.002

[129] Grovel, O., Pouchus, Y., Robiou du Pont, T., Montagu, M., Amzil, Z. and Verbist, J. (2002) Ion TRap MS(n) for Identification of Gliotoxin as the Cytotoxic Factor of a Marine Strain of Aspergillus fumigatus Fresenius. Journal of Microbiological Methods, 48, 171-179. http://dx.doi.org/10.1016/S0167-7012(01)00321-9

[130] Nieminen, S.M., Maki-Paakkanen, J., Hirvonen, M.R., Roponen, M. and von Wright, A. (2002) Genotoxicity of Gliotoxin, a Secondary Metabolite of Aspergillus fumigatus, in a Battery of Short-Term Test Systems. Mutation Research, 520, 161-170. http://dx.doi.org/10.1016/S1383-5718(02)00202-4

[131] Kweon, Y.O., Paik, Y.H., Schnabl, B., Qian, T., Lemasters, J.J. and Brenner, D.A. (2003) Gliotoxin-Mediated Apoptosis of Activated Human Hepatic Stellate Cells. Journal of Hepatology, 39, 38-46. http://dx.doi.org/10.1016/S0168-8278(03)00178-8

[132] Kruglov, A.G., Andersson, M.A., Mikkola, R., Roivainen, M., Kredics, L., Saris, N.E.L. and Salkinoja-Salonen, M.S. (2009) Novel Mycotoxin from Acremonium xuviarum Is a Powerful Inhibitor of the Mitochondrial Respiratory Chain Complex III. Chemical Research in Toxicology, 22, 565-573. http://dx.doi.org/10.1021/tx800317z

[133] Ogawa, H., Nozawa, Y., Rojanavanich, V., Tsuboi, R., Yoshiike, T., Banno, Y., Takahashi, M., Nombela, C., Herreros, E., Garcia-Saez, M.I., Santos, A.I. and Sanchez, M. (1992) Fungal Enzymes in the Pathogenesis of Fungal Infections. Journal of Medical Mycology, 30, 189-196. http://dx.doi.org/10.1080/02681219280000881

[134] Karkowska-Kuleta, J., Rapala-Kozik, M. and Kozik, A. (2009) Fungi Pathogenic to Humans: Molecular Bases of Virulence of Candida albicans, Cryptococcus neoformans and Aspergillus fumigatus. Acta Biochemica Polanica, 56, 211-224.

[135] Resnick, S., Pappagianis, D. and McKerrow, J.H. (1987) Proteinase Production by the Parasitic Cycle of the Pathogenic Fungus Coccidioides immitis. Infection and Immunity, 55, 2807-2815.

[136] Macdonald, F. and Odds, F.C. (1983) Virulence for Mice of a Proteinase-Secreting Strain of Candida albicans and a Proteinase-Deficient Mutant. Journal of General Microbiology, 129, 431-438.

[137] Borg, M. and Ruchel, R. (1988) Expression of Extracellular Acid Proteinase by Proteolytic Candida s during Experimental Infection of Oral Mucosa. Infection and Immunity, 56, 626-631.

[138] Samaranayake, Y.H., MacFarlane, T.W., Samaranayake, L.P. and Aitchison, T. (1994) The in Vitro Proteolytic and Saccharolytic Activity of Candida Species Cultured in Human Saliva. Oral Microbiology and Immunology, 9, 229-235. http://dx.doi.org/10.1111/j.1399-302X.1994.tb00063.x

[139] De Bernardis, F., Agatensi, L., Ross, I.K., Emerson, G.W., Lorenzini, R., Sullivan, P.A. and Cassone, A. (1990) Evidence for a Role for Secreted Aspartate Proteinase of Candida albicans in Vulvovaginal Candidiasis. The Journal of Infectious Diseases, 161, 1276-1283. http://dx.doi.org/10.1093/infdis/161.6.1276

[140] Schaller, M., Borelli, C., Korting, H.C. and Hube, B. (2005) Hydrolytic Enzymes as Virulence Factors of Candida al- 
bicans. Mycoses, 48, 365-377. http://dx.doi.org/10.1111/j.1439-0507.2005.01165.x

[141] Zaugg, C., Borg-Von Zepelin, M., Reichard, U., Sanglard, D. and Monod, M. (2001) Secreted Aspartic Proteinase Family of Candida tropicalis. Infection and Immunity, 69, 405-412. http://dx.doi.org/10.1128/IAI.69.1.405-412.2001

[142] Calderone, R., Hube, B. and Naglik, J.R. (2002) Extracellular Hydrolases. In: Calderone, R.A., Ed., Candida and Candidiasis, ASM Press, Washington, 107-122.

[143] Scully, C., el-Kabir, M. and Samaranayake, L.P. (1994) Candida and Oral Candidosis: A Review. Critical Reviews in Oral Biology and Medicine, 5, 125-157.

[144] Lee, J.D. and Kolattukudy, P.E. (1995) Molecular Cloning of the cDNA and Gene for an Elastinolytic Aspartic Proteinase from Aspergillus fumigatus and Evidence of Its Secretion by the Fungus during Invasion of the Host Lung. Infection and Immunity, 63, 3796-3803.

[145] Chen, S.C., Wright, L.C., Golding, J.C. and Sorrell, T.C. (2000) Purification and Characterization of Secretory Phospholipase B, Lysophospholipase and Lysophospholipase/Transacylase from a Virulent Strain of the Pathogenic Fungus Cryptococcus neoformans. Biochemical Journal, 347, 431-439.

[146] Cox, G.M., McDade, H.C., Chen, S.C., Tucker, S.C., Gottfredsson, M., Wright, L.C., Sorrell, T.C., Leidich, S.D., Casadevall, A., Ghannoum, M.A. and Perfect, J.R. (2001) Extracellular Phospholipase Activity Is a Virulence Factor for Cryptococcus neoformans. Molecular Microbiology, 39, 166-175. http://dx.doi.org/10.1046/j.1365-2958.2001.02236.x

[147] Ghannoum, M.A. (2000) Potential Role of Phospholipases in Virulence and Fungal Pathogenesis. Clinical Microbiology Reviews, 13, 122-143. http://dx.doi.org/10.1128/CMR.13.1.122-143.2000

[148] Ganendren, R., Carter, E., Sorrell, T., Widmer, F. and Wright, L. (2006) Phospholipase B Activity Enhances Adhesion of Cryptococcus neoformans to a Human Lung Epithelial Cell Line. Microbes and Infection, 8, 1006-1015. http://dx.doi.org/10.1016/j.micinf.2005.10.018

[149] Neves, R.P., Magalhães, O.M.C., da Silva, M.L., de Souza-Motta, C.M. and de Queiroz, L.A. (2005) Identification and Pathogenicity of Malassezia Species Isolated from Human Healthy Skin and with Macules. Brazilian Journal of Microbiology, 36, 114-117. http://dx.doi.org/10.1590/S1517-83822005000200003

[150] Olszewski, M.A., Noverr, M.C., Chen, G.H., Toews, G.B., Cox, G.M., Perfect, J.R. and Huffnagle, G.B. (2004) Urease Expression by Cryptococcus neoformans Promotes Microvascular Sequestration, Thereby Enhancing Central Nervous System Invasion. American Journal of Pathology, 164, 1761-1771. http://dx.doi.org/10.1016/S0002-9440(10)63734-0

[151] Li, K., Yu, J.J., Hung, C.Y., Lehmann, P.F. and Cole, G.T. (2001) Recombinant Urease and Urease DNA of Coccidioides immitis Elicit an Immunoprotective Response against Coccidioidomycosis in Mice. Infection and Immunity, 69, 2878-2887. http://dx.doi.org/10.1128/IAI.69.5.2878-2887.2001

[152] Rappleye, C.A. and Goldman, W.E. (2006) Defining Virulence Genes in the Dimorphic Fungi. Annual Review of Microbiology, 60, 281-303. http://dx.doi.org/10.1146/annurev.micro.59.030804.121055

[153] Rodrigues, M.L., Nakayasu, E.S., Oliveira, D.L., Nimrichter, L., Nosanchuk, J.D., Almeida, I.C. and Casadevall, A. (2008) Extracellular Vesicles Produced by Cryptococcus neoformans Contain Protein Components Associated with Virulence. Eukaryotic Cell, 7, 58-67. http://dx.doi.org/10.1128/EC.00370-07

[154] Gordon, M.A. and Vedder, D.K. (1966) Serologic Tests in Diagnosis and Prognosis of Cryptococcosis. The Journal of the American Medical Association, 197, 961-967. http://dx.doi.org/10.1001/jama.1966.03110120067016

[155] Jung, W.H. and Kronstad, J.W. (2008) Iron and Fungal Pathogenesis: A Case Study with Cryptococcus neoformans. Cellular Microbiology, 10, 277-284. http://dx.doi.org/10.1111/j.1462-5822.2007.01077.x

[156] Timmerman, M.M. and Woods, J.P. (1999) Ferric Reduction Is a Potential Iron Acquisition Mechanism for Histoplasma capsulatum. Infection and Immunity, 67, 6403-6408.

[157] Brown, A.J.P., Odds, F.C. and Gow, N.A.R. (2007) Infection-Related Gene Expression in Candida albicans. Current Opinion in Microbiology, 10, 307-313. http://dx.doi.org/10.1016/j.mib.2007.04.001

[158] Latgé, J.P. (2001) The Pathobiology of Aspergillus fumigatus. Trends in Microbiology, 9, 382-389. http://dx.doi.org/10.1016/S0966-842X(01)02104-7

[159] Johnson, L. (2008) Iron and Siderophores in Fungal-Host Interactions. Mycological Research, 112, 170-183. http://dx.doi.org/10.1016/j.mycres.2007.11.012

[160] Nyilasi, I., Papp, T., Takó, M., Nagy, E. and Vágvölgyi, C. (2005) Iron Gathering of Opportunistic Pathogenic Fungi. A Mini Review. Acta Microbiologica et Immunologica Hungarica, 52, 185-197. http://dx.doi.org/10.1556/AMicr.52.2005.2.4

[161] Lesuisse, E. and Labbe, P. (1994) Reductive Iron Assimilation in Saccharomyces cerevisiae. In: Winkelmann, G. and Winge, D.R., Eds., Metal Ions in Fungi, Marcel Dekker, New York, 149-178.

[162] Neilands, J.B. (1995) Siderophores: Structure and Function of Microbial Iron Transport Compounds. Journal of Biological Chemistry, 270, 26723-26726. 
[163] Lesuisse, E., Simon-Casteras, M. and Labbe, P. (1998) Siderophore-Mediated Iron Uptake in Saccharomyces cerevisiae: The SIT1 Gene Encodes a Ferrioxamine B Permease that Belongs to the Major Facilitator Superfamily. Microbiology, 144, 3455-3462. http://dx.doi.org/10.1099/00221287-144-12-3455

[164] Crowley, D.E., Wang, Y.C., Reid, C.P.P. and Szaniszlo, P.J. (1991) Mechanisms of Iron Acquisition from Siderophores by Microorganisms and Plants. Plant and Soil, 130, 179-198. http://dx.doi.org/10.1007/BF00011873

[165] Hider, R. (1984) Siderophore Mediated Absorption of Iron. Structure and Bonding, 58, 25-87. http://dx.doi.org/10.1007/BFb0111310

[166] Holzberg, M. and Artis, W.M. (1983) Hydroxamate Siderophore Production by Opportunistic and Systemic Fungal Pathogens. Infection and Immunity, 40, 1134-1139.

[167] Dave, B.P. and Dube, H.C. (2000) Chemical Characterization of Fungal Siderophores. Indian Journal of Experimental Biology, 38, 56-62.

[168] Howard, D.H. (1999) Acquisition, Transport, and Storage of Iron by Pathogenic Fungi. Clinical Microbiology Reviews, 12, 394-404.

[169] van Burik, J.A. and Magee, P.T. (2001) Aspects of Fungal Pathogenesis in Humans. Annual Review of Microbiology, 55, 743-772. http://dx.doi.org/10.1146/annurev.micro.55.1.743

[170] Petrik, M., Haas, H., Schrettl, M., Helbok, A., Blatzer, M. and Decristoforo, C. (2012) In Vitro and in Vivo Evaluation of Selected 68Ga-Siderophores for Infection Imaging. Nuclear Medicine and Biology, 39, 361-369. http://dx.doi.org/10.1016/j.nucmedbio.2011.09.012

[171] Schrettl, M., Ibrahim-Granet, O., Droin, S., Huerre, M., Latge, J.P. and Haas, H. (2010) The Crucial Role of the Aspergillus fumigatus Siderophore System in Interaction with Alveolar Macrophages. Microbes and Infection, 12, 1035-1041. http://dx.doi.org/10.1016/j.micinf.2010.07.005

[172] Johnson, L. (2008) Iron and Siderophores in Fungal-Host Interactions. Mycological Research, 112, 170-183. http://dx.doi.org/10.1016/j.mycres.2007.11.012

[173] Blatzer, M., Schrettl, M., Sarg, B., Lindner, H.H., Pfaller, K. and Haas, H. (2011) SidL, an Aspergillus fumigatus Transacetylase Involved in Biosynthesis of the Siderophores Ferricrocin and Hydroxyferricrocin. Applied and Environmental Microbiology, 77, 4959-4966. http://dx.doi.org/10.1128/AEM.00182-11

[174] Haas, H., Eisendle, M. and Turgeon, B.G. (2008) Siderophores in Fungal Physiology and Virulence. Annual Review of Phytopathology, 46, 149-187. http://dx.doi.org/10.1146/annurev.phyto.45.062806.094338

[175] Howard, D.H., Rafie, R., Tiwari, A. and Faull, K.F. (2000) Hydroxamate Siderophores of Histoplasma capsulatum. Infection and Immunity, 68, 2338-2343. http://dx.doi.org/10.1128/IAI.68.4.2338-2343.2000

[176] Schrettl, M., Bignell, E., Kragl, C., Joechl, C., Rogers, T., Arst Jr., H.N., Haynes, K. and Haas, H. (2004) Siderophore Biosynthesis but not Reductive Iron Assimilation Is Essential for Aspergillus fumigatus Virulence. Journal of Experimental Medicine, 200, 1213-1219. http://dx.doi.org/10.1084/jem.20041242

[177] Yasmin, S., Alcazar-Fuolib, L., Gründlingera, M., Puempelc, T., Cairnsb, T., Blatzera, M., Lopezd, J.F., Grimaltd, J.O., Bignellb, E. and Haas, H. (2012) Mevalonate Governs Interdependency of Ergosterol and Siderophore Biosyntheses in the Fungal Pathogen Aspergillus fumigatus. Proceedings of the National Academy of Sciences of the United States of America, 109, E497-E504. http://dx.doi.org/10.1073/pnas.1106399108

[178] Eisendle, M., Oberegger, H., Zadra, I. and Haas, H. (2003) The Siderophore System Is Essential for Viability of Aspergillus nidulans: Functional Analysis of Two Genes Encoding L-Ornithine $\mathrm{N}^{5}$-Monooxygenase (sidA) and a Non-Ribosomal Peptide Synthetase (sidC). Molecular Microbiology, 49, 359-375. http://dx.doi.org/10.1046/j.1365-2958.2003.03586.x

[179] Winkelmann, G. (1992) Structures and Functions of Fungal Siderophores Containing Hydroxamate and Complexone Type Iron Binding Ligands. Mycological Research, 96, 529-534. http://dx.doi.org/10.1016/S0953-7562(09)80976-3

[180] van der Helm, D. and Winkelmann, G. (1994) Hydroxamates and Polycarboxylates as Iron Transport Agents (Siderophores) in Fungi. In: Winkelmann, G. and Winge, D.R., Eds., Metal Ions in Fungi, Marcel Dekker, Inc., New York, 39-98.

[181] Winkelmann, G. (1990) Structural and Stereochemical Aspects of Iron Transport in Fungi. Biotechnology Advances, 8, 207-231. http://dx.doi.org/10.1016/0734-9750(90)90013-2

[182] van der Helm, D., Jalal, M.A.F. and Hossain, M.B. (1987) The Crystal Structures, Conformations and Configurations of Siderophores. In: Inkelmann, G., van der Helm, D. and Neilands, J.B., Eds., Iron Transport in Microbes, Plants and Animals, VCH, Weinheim, 135-165.

[183] Burt, W.R. (1982) Identification of Coprogen B and Its Breakdown Products from Histoplasma capsulatum. Infection and Immunity, 35, 990-996.

[184] Frederick, C.B., Szaniszlo, P.J., Vickrey, P.E., Bentley, M.D. and Shive, W. (1981) Production and Isolation of Side- 
rophores from the Soil Fungus Epicoccum purpurescens. Biochemistry, 20, 2432-2436. http://dx.doi.org/10.1021/bi00512a010

[185] Leong, S.A. and Winkelmann, G. (1998) Molecular Biology of Iron Transport in Fungi. In: Sigel, A. and Sigel, H., Eds., Metal Ions in Biological Systems, Marcel Dekker, New York, 147-186.

[186] Burt, W.R. (1983) Isolation of Hydroxamic Acids from Blastomyces dermatitidis. Abstracts of the Annual Meeting of the American Society for Microbiology, abstr. Washington, American Society for Microbiology, F17, 385.

[187] Crichton, R.R. (1991) Inorganic Biochemistry of Iron Metabolism. Ellis Horwood, Chichester.

[188] Mor, H., Kashman, Y., Winkelmann, G. and Barash, I. (1992) Characterization of Siderophores Produced by Different Species of the Dermatophytic Fungi Microsporum and Trichophyton. Biometals, 5, 213-216. http://dx.doi.org/10.1007/BF01061220

[189] Bentley, M.D., Anderegg, R.J., Szaniszlo, P.J. and Davenport, R.F. (1986) Isolation and Identification of the Principal Siderophore of the Dermatophyte Microsporum gypseum. Biochemistry, 25, 1455-1457. http://dx.doi.org/10.1021/bi00354a040

[190] Drechsel, H., Metzger, J., Freund, S., Jung, G., Boelaert. J. and Winkelmann, G. (1991) Rhizoferrin-A Novel Siderophore from the Fungus Rhizopus microsporus var. rhizopodiformis. Biology of Metals, 4, 238-243. http://dx.doi.org/10.1007/BF01141187

[191] Drechsel, H., Tschierske, M., Thieken, A., Jung, G., Zähner, H. and Winkelmann, G. (1995) The Carboxylate Type Siderophore Rhizoferrin and Its Analogs Produced by Directed Fermentation. Journal of Industrial Microbiology, 14, 105-112. http://dx.doi.org/10.1007/BF01569891

[192] Brakhage, A.A. and Liebmann, B. (2005) Aspergillus fumigatus Conidial Pigment and cAMP Signal Transduction: Significance for Virulence. Medical Mycology, 43, S75-S82. http://dx.doi.org/10.1080/13693780400028967

[193] Henson, J.M., Butler, M.J. and Day, A.W. (1999) The Dark Side of the Mycelium: Melanins of Phytopathogenic Fungi. Annual Review of Phytopathology, 37, 447-471. http://dx.doi.org/10.1146/annurev.phyto.37.1.447

[194] Jacobson, E.S. (2000) Pathogenic Roles for Fungal Melanins. Clinical Microbiology Reviews, 13, 708-717. http://dx.doi.org/10.1128/CMR.13.4.708-717.2000

[195] Bell, A.A. and Wheeler, M.H. (1986) Biosynthesis and Functions of Fungal Melanins. Annual Review of Phytopathology, 24, 411-451. http://dx.doi.org/10.1146/annurev.py.24.090186.002211

[196] Haase, G. and Brakhage, A.A. (2004) Melanized Fungi Infecting Humans: Function of Melanin as a Pathogenicity Factor. In: Domer, J.E. and Kobayashi, G.S., Eds., The Mycota: Human Fungal Pathogens, Springer, XII, Berlin, 67-87. http://dx.doi.org/10.1007/978-3-662-10380-7_4

[197] Hamilton, A.J. and Gomez, B.L. (2002) Melanins in Fungal Pathogens. Journal of Medical Microbiology, 51, $189-191$.

[198] Butler, J.M. and Day, A.W. (1998) Fungal Melanins: A Review. Canadian Journal of Microbiology, 44, $1115-1136$. http://dx.doi.org/10.1139/w98-119

[199] Jacobson, E.S. and Ikeda, R. (2005) Effect of Melanization upon Porosity of the Cryptococcal Cell Wall. Medical Mycology, 43, 327-333. http://dx.doi.org/10.1080/13693780412331271081

[200] Romero-Martinez, R., Wheeler, M., Guerrero-Plata, A., Rico, G. and Torres-Guerrero, H. (2000) Biosynthesis and Function of Melanin in Sporothrix schenckii. Infection and Immunity, 68, 3696-3703. http://dx.doi.org/10.1128/IAI.68.6.3696-3703.2000

[201] Dadachova, E. and Casadevall, A. (2008) Ionizing Radiation: How Fungi Cope, Adapt, and Exploit with the Help of Melanin. Current Opinion in Microbiology, 11, 525-531. http://dx.doi.org/10.1016/j.mib.2008.09.013

[202] Dadachova1, E., Bryan, R.A., Howell, R.C., Schweitzer, A.D., Aisen, P., Nosanchuk, J.D. and Casadevall, A. (2007) The Radioprotective Properties of Fungal Melanin Are a Function of Its Chemical Composition, Stable Radical Presence and Spatial Arrangement. Pigment Cell \& Melanoma Research, 21, 192-199. http://dx.doi.org/10.1111/j.1755-148X.2007.00430.X

[203] Kawamura, C., Moriwaki, J., Kimura, N., Fujita, Y., Fuji, S., Hirano, K., Koizumi, S. and Tsuge, T. (1997) The Melanin Biosynthesis Genes of Alternaria alternata Can Restore Pathogenicity of the Melanin Deficient Mutant of Magnaporthe grisea. Molecular Plant-Microbe Interactions, 10, 446-453. http://dx.doi.org/10.1094/MPMI.1997.10.4.446

[204] Singaravelan, N., Grishkan, I., Beharav, A., Wakamatsu, K., Ito, S. and Nevo, E. (2008) Adaptive Melanin Response of the Soil Fungus Aspergillus niger to UV Radiation Stress at 'Evolution Canyon', Mount Carmel, Israel. PLOS ONE, 3, Article ID: e2993. http://dx.doi.org/10.1371/journal.pone.0002993

[205] Butler, J.M., Day, A.W., Henson, J.M. and Money, N.P. (2001) Pathogenic Properties of Fungal Melanins. Mycologia, 93, 1-8. http://dx.doi.org/10.2307/3761599

[206] Kuo, M.J. and Alexander, M. (1967) Inhibition of the Lysis of Fungi by Melanins. Journal of Bacteriology, 94, 624629. 
[207] Gunde-Cimerman, N. and Plemenitaš, A. (2006) Ecology and Molecular Adaptations of the Halophilic Black Yeast Hortaea werneckii. Reviews in Environmental Science and Biotechnology, 5, 323-331. http://dx.doi.org/10.1007/s11157-006-9105-0

[208] Gadd, G.M., Gray, D.J. and Newby, P.J. (1990) Role of Melanin in Fungal Biosorption of Tributyltin Chloride. Applied Microbiology and Biotechnology, 34, 116-121. http://dx.doi.org/10.1007/BF00170934

[209] Babior, B.M. (1978) Oxygen-Dependent Microbial Killing by Phagocytes. The New England Journal of Medicine, 298, 659-668. http://dx.doi.org/10.1056/NEJM197803232981205

[210] Jacobson, E.S. and Hong, J.D. (1997) Redox Buffering by Melanin and Fe(II) in Cryptococcus neoformans. Journal of Bacteriology, 179, 5340-5346.

[211] Jacobson, E.S. and Emery, H.S. (1991) Catecholamine Uptake, Melanization, and Oxygen Toxicity in Cryptococcus neoformans. Journal of Bacteriology, 173, 401-403.

[212] Jacobson, E.S. and Tinnell, S.B. (1993) Antioxidant Function of Fungal Melanin. Journal of Bacteriology, 175, 71027104.

[213] Wang, Y. and Casadevall, A. (1994) Susceptibility of Melanized and Nonmelanized Cryptococcus neoformans to Nitrogen- and Oxygen-Derived Oxidants. Infection and Immunity, 62, 3004-3007.

[214] Wang, Y., Aisen, P. and Casadevall, A. (1995) Cryptoccus neoformans Melanin and Virulence: Mechanism of Action. Infection and Immunity, 63, 3131-3136.

[215] Rosas, Á.L., Nosanchuk, J.D., Feldmesser, M., Cox, G.M., Mcdade, H.C. and Casadevall, A. (2000) Synthesis of Polymerized Melanin by Cryptococcus neoformans in Infected Rodents. Infection and Immunity, 68, 2845-2853. http://dx.doi.org/10.1128/IAI.68.5.2845-2853.2000

[216] Gómez, B.L., Nosanchuk, J.D., Díez, S., Youngchim, S., Aisen, P., Cano, L.E., Restrepo, A., Casadevall, A. and Hamilton, A.J. (2001) Detection of Melanin-Like Pigments in the Dimorphic Fungal Pathogen Paracoccidioides brasiliensis in Vitro and during Infection. Infection and Immunity, 69, 5760-5767. http://dx.doi.org/10.1128/IAI.69.9.5760-5767.2001

[217] Morris-Jones, R., Gomez, B.L., Diez, S., Uran, M., Morris-Jones, S.D., Casadevall, A., Nosanchuk, J.D. and Hamilton, A.J. (2005) Synthesis of Melanin Pigment by Candida albicans in Vitro and during Infection. Infection and Immunity, 73, 6147-6150. http://dx.doi.org/10.1128/IAI.73.9.6147-6150.2005

[218] Ajello, L. (1975) Phaeohyphomycosis: Definition and Etiology. Pan American Health Organization Scientific Publications, 304, 126-133.

[219] Rossmann, S.N., Cernoch, P.L. and Davis, J.R. (1996) Dematiaceous Fungi Are an Increasing Cause of Human Disease. Clinical Infectious Diseases, 22, 73-80. http://dx.doi.org/10.1093/clinids/22.1.73

[220] McGinnis, M.R., Rinaldi, M.G. and Winn, R.E. (1986) Emerging Agents of Phaeohyphomycosis: Pathogenic Species of Bipolaris and Exserohilum. Journal of Clinical Microbiology, 24, 250-259.

[221] Revankar, S.G. (2007) Dematiaceous Fungi. Mycoses, 50, 91-101. http://dx.doi.org/10.1111/j.1439-0507.2006.01331.x

[222] Revankar, S.G., Sutton, D.A. and Rinaldi, M.G. (2004) Primary Central Nervous System Phaeohyphomycosis: A Review of 101 Cases. Clinical Infectious Diseases, 38, 206-216. http://dx.doi.org/10.1086/380635

[223] Nosanchuk, J.D. and Casadevall, A. (2006) Impact of Melanin on Microbial Virulence and Clinical Resistance to Antimicrobial Compounds. Antimicrobial Agents and Chemotherapy, 50, 3519-3528. http://dx.doi.org/10.1128/AAC.00545-06

[224] Cutler, J.E. and Swatek, F.E. (1969) Pigment Production by Basidiobolus in the Presence of Tyrosine. Mycologia, 60, 130-135. http://dx.doi.org/10.2307/3757351

[225] da Silva, M.B., Marques, A.F., Nosanchuk, J.D., Casadevall, A., Travassos, L.R. and Taborda, C.P. (2006) Melanin in the Dimorphic Fungal Pathogen Paracoccidioides brasiliensis: Effects on Phagocytosis, Intracellular Resistance and Drug Susceptibility. Microbes and Infection, 8, 197-205. http://dx.doi.org/10.1016/j.micinf.2005.06.018

[226] Dixon, D.M., Migliozzi, J., Cooper Jr., C.R., Solis, O., Breslin, B. and Szaniszlo, P.J. (1992) Melanized and Non-Melanized Multicellular form Mutants of Wangiella dermatitidis in Mice: Mortality and Histopathology Studies. Mycoses, 35, 17-21. http://dx.doi.org/10.1111/j.1439-0507.1992.tb00814.x

[227] Jahn, B., Koch, A., Schmidt, A., Wanner, G., Gehringer, H., Bhakdi, S. and Brakhage, A.A. (1997) Isolation and Characterization of a Pigmentless-Conidium Mutant of Aspergillus fumigatus with Altered Conidial Surface and Reduced Virulence. Infection and Immunity, 65, 5110-5117.

[228] Prescott, L.M. (2002) Microbiology. 5th Edition, McGraw-Hill, New York.

[229] Geis, P.A. and Szaniszlo, P. (1984) Carotenoid Pigments of the Dematiaceous Fungus Wangiella dermatitidis. Mycologia, 76, 268-273. http://dx.doi.org/10.2307/3793103

[230] Schnitzler, N., Peltroche-Llacsahuanga, H., Bestier, N., Zündorf, J., Lütticken, R. and Haase, G. (1999) Effect of Me- 
lanin and Carotenoids of Exophiala (Wangiella) dermatitidis on Phagocytosis, Oxidative Burst, and Killing by Human Neutrophils. Infection and Immunity, 67, 94-101.

[231] Dixon, D.M., Polak, A. and Szaniszlo, P.J. (1987) Pathogenicity and Virulence of Wild-Type and Melanin-Deficient Wangiella dermatitidis. Journal of Medical Mycology, 25, 97-106.

http://dx.doi.org/10.1080/02681218780000141

[232] Dixon, D.M., Polak, A. and Conner, G.W. (1989) Mel-Mutants of Wangiella dermatitidis in Mice: Evaluation of Multiple Mouse and Fungal Strains. Journal of Medical Mycology, 27, 335-341. http://dx.doi.org/10.1080/02681218980000451

[233] Tuon, F.F. and Costa, S.F. (2008) Rhodotorula Infection. A Systematic Review of 128 Cases from Literature. Revista Iberoamericana de Micología, 25, 135-140. http://dx.doi.org/10.1016/S1130-1406(08)70032-9

[234] Chan, G.F., Puad, M.S., Chin, C.F. and Rashid, N.A. (2011) Emergence of Aureobasidium pullulans as Human Fungal Pathogen and Molecular Assay for Future Medical Diagnosis. Folia Microbiologica, 56, 459-467. http://dx.doi.org/10.1007/s12223-011-0070-9

[235] Clark, E.C., Silver, S.M., Hollick, G.E. and Rinaldi, M.G. (1995) Continuous Ambulatory Peritoneal Dialysis Complicated by Aureobasidium pullulans Peritonitis. American Journal of Nephrology, 15, 353-355. http://dx.doi.org/10.1159/000168863

[236] Salkin, I.F., Martinez, J.A. and Kemna, M.E. (1986) Opportunistic Infection of the Spleen Caused by Aureobasidium pullulans. Journal of Clinical Microbiology, 23, 828-831.

[237] Niedoszytko, M., Chełminska, M., Jassem, E. and Czestochowska, E. (2007) Association between Sensitization to Aureobasidium pullulans (Pullularia sp) and Severity of Asthma. Annals of Allergy, Asthma \& Immunology, 98, 153-156. http://dx.doi.org/10.1016/S1081-1206(10)60688-6

[238] Pouliot, J.M., Walton, I., Nolen-Parkhouse, M., Abu-Lail, L.I. and Camesano, T.A. (2005) Adhesion of Aureobasidium pullulans Is Controlled by Uronic Acid Based Polymers and Pullulan. Biomacromolecules, 6, 1122-1131. http://dx.doi.org/10.1021/bm0492935

[239] San-Blas, G. and San-Blas, F. (1977) Paracoccidioides Brasiliensis: Cell Wall Structure and Virulence. A Review. Mycopathologia, 62, 77-86. http://dx.doi.org/10.1007/BF01259396

[240] Hogan, L.H. and Klein, B.S. (1994) Altered Expression of Surface Alpha-1,3-Glucan in Genetically Related Strains of Blastomyces dermatitidis that Differ in Virulence. Infection and Immunity, 62, 3543-3546.

[241] Klimpel, K.R. and Goldman, W.E. (1988) Cell Walls from a Virulent Variants of Histoplasma capsulatum Lack $\alpha$-(1-3)-Glucan. Infection and Immunity, 56, 2997-3000.

[242] Liappis, A.P., Kan, V.L., Richman, N.C., Yoon, B., Wong, B. and Simon, G.L. (2008) Mannitol and Inflammatory Markers in the Cerebral Spinal Fluid of HIV-Infected Patients with Cryptococcal Meningitis. European Journal of Clinical Microbiology \& Infectious Diseases, 27, 477-479. http://dx.doi.org/10.1007/s10096-008-0462-1

[243] Wong, B., Perfect, J.R., Beggs, S. and Wright, K.A. (1990) Production of the Hexitol D-Mannitol by Cryptococcus neoformans in Vitro and in Rabbits with Experimental Meningitis. Infection and Immunity, 58, 1664-1670.

[244] Chaturvedi, V., Wong, B. and Newman, S.L. (1996) Oxidative Killing of Cryptococcus neoformans by Human Neutrophils. Evidence that Fungal Mannitol Protects by Scavenging Reactive Oxygen Intermediates. Journal of Immunology, 156, 3836-3840.

[245] Chaturvedi, V., Flynn, T., Niehaus, W.G. and Wong, B. (1996) Stress Tolerance and Pathogenic Potential of a Mannitol Mutant of Cryptococcus neoformans. Microbiology, 142, 937-943.

[246] Weissman, Z. and Kornitzer, D. (2004) A Family of Candida Cell Surface Haem-Binding Proteins Involved in Haemin and Haemoglobin-Iron Utilization. Molecular Microbiology, 53, 1209-1220. http://dx.doi.org/10.1111/j.1365-2958.2004.04199.x

[247] Sheppard, D.C., Yeaman, M.R., Welch, W.H., Phan, Q.T., Fu, Y., Ibrahim, A.S., Filler, S.G., Zhang, M., Waring, A.J. and Edwards Jr., J.E. (2004) Functional and Structural Diversity in the Als Protein Family of Candida albicans. Journal of Biological Chemistry, 279, 30480-30489. http://dx.doi.org/10.1074/jbc.M401929200

[248] Klein, B.S., Hogan, L.H. and Jones, J.M. (1993) Immunological Recognition of a 25-Amino Acid Repeat Arrayed in Tandem on a Major Antigen of Blastomyces dermatitidis. The Journal of Clinical Investigation, 92, 330-337. http://dx.doi.org/10.1172/JCI116571

[249] Almeida, S.R., Unterkircher, C.S. and Camargo, Z.P. (1998) Involvement of the Major Glycoprotein (gp43) of Paracoccidioides brasiliensis in Attachment to Macrophages. Medical Mycology, 36, 405-411. http://dx.doi.org/10.1080/02681219880000641

[250] Van Ho, A., Ward, D.M. and Kaplan, J. (2002) Transition Metal Transport in Yeast. Annual Review of Microbiology, 56, 237-261. http://dx.doi.org/10.1146/annurev.micro.56.012302.160847 
[251] Navarathna, D.H.L.P., Hornby, J.M., Krishnan, N., Parkhurst, A., Duhamel, G.E. and Nickerson, K.W. (2007) Effect of Farnesol on a Mouse Model of Systemic Candidiasis, Determined by Use of a DPP3 Knockout Mutant of Candida albicans. Infection and Immunity, 75, 1609-1618.

[252] Navarathna, D.H.L.P., Nickerson, K.W., Duhamel, G.E., Jerrels, T.R. and Petro, T.M. (2007) Exogenous Farnesol Interferes with the Normal Progression of Cytokine Expression during Candidiasis in a Mouse Model. Infection and Immunity, 75, 4006-4011. http://dx.doi.org/10.1128/IAI.00397-07

[253] Chiapello, L.S., Baronetti, J.L., Garro, A.P., Spesso, M.F. and Masih, D.T. (2008) Cryptococcus neoformans Glucuronoxylomannan Induces Macrophage Apoptosis Mediated by Nitric Oxide in a Caspase-Independent Pathway. International Immunology, 20, 1527-1541. http://dx.doi.org/10.1093/intimm/dxn112

[254] Tucker, S.C. and Casadevall, A. (2002) Replication of Cryptococcus neoformans in Macrophages Is Accompanied by Phagosomal Permeabilization and Accumulation of Vesicles Containing Polysaccharide in the Cytoplasm. Proceedings of the National Academy of Sciences of the United States of America, 99, 3165-3170. http://dx.doi.org/10.1073/pnas.052702799

[255] Ellerbroek, P.M., Lefeber, D.J., van Veghel, R., Scharringa, J., Brouwer, E., Gerwig, G.J., Janbon, G., Hoepelman, A.I. and Coenjaerts, F.E. (2004) O-Acetylation of Cryptococcal Capsular Glucuronoxylomannan Is Essential for Interference with Neutrophil Migration. The Journal of Immunology, 173, 7513-7520.

[256] Villena, S.N., Pinheiro, R.O., Pinheiro, C.S., Nunes, M.P., Takiya, C.M., Dosreis, G.A., Previato, J.O., MendoncaPreviato, L. and Freire-de-Lima, C.G. (2008) Capsular Polysaccharides Galactoxylomannan and Glucuronoxylomannan from Cryptococcus neoformans Induce Macrophage Apoptosis Mediated by Fas Ligand. Cellular Microbiology, 10, 1274-1285. http://dx.doi.org/10.1111/j.1462-5822.2008.01125.x

[257] Yauch, L.E., Lam, J.S. and Levitz, S.M. (2006) Direct Inhibition of T-Cell Responses by the Cryptococcus Capsular Polysaccharide Glucuronoxylomannan. PLOS Pathogens, 2, 1060-1068. http://dx.doi.org/10.1371/journal.ppat.0020120

[258] Monari, C., Bistoni, F. and Vecchiarelli, A. (2006) Glucuronoxylomannan Exhibits Potent Immunosuppressive Properties. FEMS Yeast Research, 6, 537-542. http://dx.doi.org/10.1111/j.1567-1364.2006.00072.x

[259] Lupo, P., Chang, Y.C., Kelsall, B.L., Farber, J.M., Pietrella, D., Vecchiarelli, A., Leon, F. and Kwon-Chung, K.J. (2008) The Presence of Capsule in Cryptococcus neoformans Influences the Gene Expression Profile in Dendritic Cells during Interaction with the Fungus. Infection and Immunity, 76, 1581-1589. http://dx.doi.org/10.1128/IAI.01184-07

[260] Denning, D.W., Armstrong, R.W., Lewis, B.H. and Stevens, D.A. (1991) Elevated Cerebrospinal Fluid Pressures in Patients with Cryptococcal Meningitis and Acquired Immunodeficiency Syndrome. American Journal of Medicine, 91, 267-272. http://dx.doi.org/10.1016/0002-9343(91)90126-I

[261] Lyman, C.A., Devi, S.J., Nathanson, J., Frasch, C.E., Pizzo, P.A. and Walsh, T.J. (1995) Detection and Quantitation of the Glucuronoxylomannan-Like Polysaccharide Antigen from Clinical and Nonclinical Isolates of Trichosporon beigelii and Implications for Pathogenicity. Journal of Clinical Microbiology, 33, 126-130. 